\title{
Carbon storage in degraded cork oak (Quercus suber) forests on flat lowlands in Morocco
}

\author{
Hayat Oubrahim ${ }^{(1)}$, \\ Mohamed Boulmane ${ }^{(2)}$, \\ Mark R Bakker ${ }^{(3-4)}$, \\ Laurent Augusto ${ }^{(3-4)}$, \\ Mohammed Halim ${ }^{(1)}$
}

\begin{abstract}
The present study aims to quantify the carbon stored in a degraded cork oak (Quercus suber L.) ecosystem in the north west of Morocco, in view of potential management implications. To this end, carbon stocks were evaluated in the first $100 \mathrm{~cm}$ of the soil, the cork oak trees, and the understorey species (both above- and belowground). Results show that the total carbon stocks in the cork oak ecosystem ranges from 65 to $237 \mathrm{Mg} \mathrm{ha}^{-1}$ with a mean value of $121 \mathrm{Mg} \mathrm{ha}^{-1}$. The first $100 \mathrm{~cm}$ of the soil (including the forest floor) represents the largest carbon pool ( $\sim 51 \%$ of the total organic carbon) of the ecosystem. Tree biomass (above- and belowground tissues of cork oak) represents the second largest pool (47\%), whereas the contribution of the understorey is less than $2 \%$. Within the first $100 \mathrm{~cm}$ of the soil, over $87 \%$ of all the soil organic carbon is situated in the first $40 \mathrm{~cm}$ of the soil depth. The amount of carbon stored here ranges from 30 to $110 \mathrm{Mg} \mathrm{ha}^{-1}$ and these organic carbon stocks vary considerably with the stand basal area of the cork oak $\left(R^{2}=0.82\right)$. In practice, the carbon stocks of the different pools considered are strongly correlated with the stand density of the cork oak stands. In the semi-arid forest ecosystems of our study, management prescriptions aiming at increasing the standing biomass of the cork oak should thus considerably contribute, both directly through tree biomass and indirectly through increased soil organic matter, to efficient carbon sequestration.
\end{abstract}

\section{Keywords: Quercus suber, Mamora, Carbon Storage, Biomass, Litter and Soil}

\section{Introduction}

Emissions of $\mathrm{CO}_{2}$ have largely contributed to the observed changes in global climate over the last decades (IPCC 2007) and the link with human activities is no longer debated (Hansen \& Sato 2004). Terrestrial ecosystems represent a considerable part of global carbon stocks (IPCC 2013) and of all terrestrial ecosystems, forest ecosystems make up the largest part, containing around $80 \%$ of the aboveground and $40 \%$ of the belowground terrestrial carbon ( $\mathrm{Di}$ xon et al. 1994). Soils represent roughly two-thirds of the terrestrial carbon in forests, but this varies across biomes with $85 \%$ in boreal forests, $60 \%$ in temperate forests and $50 \%$ in tropical rain forests ( $\mathrm{Di}$ - xon et al. 1994). Forest soils account for $35 \%$ of the global soil C stock (Robert 2002) and this value is 2-3 times higher than the $C$ contained in the atmosphere (Makipaa et al. 1999, Schlesinger 2000, Ducroux et al. 2001). Clearly, whether such ecosystems are a source or a sink is thus a critical issue for the evolution of the carbon concentration in the atmosphere. At the same time, increased $\mathrm{CO}_{2}$ levels in the atmosphere have been shown to lead to increased sequestration in terrestrial ecosystems (Norby et al. 2005), in particular in forests. The extent to which this may occur will depend on local site conditions such as climate, nutrient and water availability, stand vitality, latitude, tree age or species (Pajot

(1) Université Mohammed V Agdal - Faculté des Sciences- Rabat, Address: 4 Avenue Ibn Battouta B.P. 1014 RP, 10000 Rabat (Morocco); (2) Laboratoire de Pédologie, Centre de Recherche Forestière, B.P. 763, Av. Omar Ibn Khattab Agdal-Rabat, 10000 Rabat (Morocco); (3) Bordeaux Sciences Agro, UMR 1391 ISPA, F-33170 Gradignan (France); (4) INRA, UMR 1391 ISPA, F-33140 Villenave d'Ornon (France)

@ Hayat Oubrahim (h.oubrahim@gmail.com)

Received: May 30, 2014 - Accepted: Mar 30, 2015

Citation: Oubrahim H, Boulmane M, Bakker MR, Augusto L, Halim M (2015). Carbon storage in degraded cork oak (Quercus suber) forests on flat lowlands in Morocco. iForest 9: 125-137. doi: 10.3832/ifor1364-008 [online 2015-08-08]

Communicated by: Giorgio Matteucci

2006, De Graaff et al. 2006, Elser et al. 2007, Dijkstra \& Cheng 2008), but also on anthropogenic influences, such as management, land degradation, or overexploitation (Pajot 2006, Lal 2005, Jandl et al. 2007). Clearing vegetation or removing the forest is estimated to account for $17 \%$ of the total emissions of greenhouse gases (IPCC 2007), and recently emphasis has been laid on this in developing countries. However, to our knowledge, the effect of human (over-) exploitation on carbon storage in these forested ecosystems has not been fully addressed. Typically, carbon accounting studies or predictive models highlight differences between boreal, temperate and tropical rain forests (Pan et al. 2011), but do not present any values for arid or semi-arid regions. According to the FAO (2006), the carbon stocks in forested ecosystems in North Africa (including biomass, dead organic debris, forest floors and the first $30 \mathrm{~cm}$ of the soil) were on average $64.9 \mathrm{Mg} \mathrm{ha}^{-1}$. Many forested ecosystems in these climates, such as those around the Mediterranean basin, are characterized by low stocking for the overstorey species, with variable amounts of understorey. In the present study, we tried to characterize carbon pools of stands typical of the Mediterranean basin: a cork oak forest.

Cork oak (Quercus suber L.) is a species endemic to the Mediterranean basin and has been present in the western Mediter- 
ranean for more than 60 million years. Its distribution range has greatly decreased as a result of the large variations in climatic conditions during this long period, but above all due to human activities (De Sousa et al. 2008). Cork oak forests in Morocco are representative of semi-arid forested ecosystems, often suffering from overexploitation, and currently they cover approximately 377500 ha (SEIFN 2006), equal to $15 \%$ of the world's cork oak forests. From the ecological, economical and societal point of view, these cork oak forests are of great value. The cork oak forests of the coastal plains in the Mamora region covered more than 130000 ha at the beginning of the $20^{\text {th }}$ century (Emberger 1939), whereas the cork oak makes up less than 60000 ha at present (Aafi et al. 2005b). The regression in surface area of the cork oak forests in Mamora is mainly due to the pressure of mankind and its livestock. Indeed, while the human population totals 300000 inhabitants living in 300 villages, the Mamora region also has no less than 225000 sheep and cows (Laaribya et al. 2013). Between 1913 and 1958, human activities were held responsible for the disappearance of up to 60000 trees per year due to programmed or illegal exploitation, harvest of firewood, collection of aromatic or medicinal plants, fires, intensification of pasture grazing by livestock, cork exploitation from bark, charcoal production or transformation to crop lands for local needs (Boudy 1952). These rural pressures, combined with more frequently occurring water stress in drought periods and insect attacks (El-Badri \& Abadie 2000, Lumaret et al. 2005, Ghaioule et al. 2007) have led to a degradation of the cork oak ecosystem. In addition to rural pressures, the cork oak forest of Mamora is influenced by several surrounding cities, thereby exposing the forest to leisure activities as well as uncontrolled urbanization (Laouina et al. 2010). As a result of all these factors of forest degradation and regression, the specific composition of the forest is disturbed, recruitment of new saplings has become almost impossible (Benabid 2000), and its surface area has greatly decreased over the last century (Aafi 2007).

Despite the relevance for the local economy and ecology, intensive use by mankind has resulted in severe degradation of the forest vegetation, stand structure and tree stocking. Restrictions of cutting and collection of firewood or acorns, along with many efforts to rehabilitate and replant the forest, have not been able to fully compensate for the degradation due to intensive use. A challenging issue, not addressed hitherto, is the actual and potential for carbon storage in such degraded low stocked forests. To this end, our study targets the quantification of carbon storage in this flat lowland cork oak forest. Our objectives were to: (1) quantify the carbon storage in a Mediterranean degraded forest ecosystem, such as the cork oak forest of Mamo- ra; (2) assess the local determinants of carbon storage of degraded land; and (3) derive prescriptions for management schemes and optimization of carbon storage.

\section{Materials and methods}

\section{Site description}

The Mamora forest is located in the north west of Morocco close to the Atlantic Ocean, between $6^{\circ}$ and $6^{\circ} 45^{\prime} \mathrm{W}$ and $34^{\circ}$ and $34^{\circ} 20^{\prime} \mathrm{N}$ (Fig. S1 in Appendix 1). The topography is flat with altitudes ranging from $6-8 \mathrm{~m}$ close to the coast up to $300 \mathrm{~m}$ in the north easterly corner. The gentle slopes are oriented from south-west to the north-east and this flat topography enables easy access to and circulation in the forest. The Mamora geological formations are mostly marine deposits from the Pliocene to the Pleistocene (Aafi et al. 2005a) with sandy soils overlying a clayey substratum. Soils are sandy and slightly acidic throughout the region. They are classified as arenosols, based on the WRB nomenclature (FAO/IUSS 2006). The climate is Mediterranean with mean air temperatures ranging from $11{ }^{\circ} \mathrm{C}$ in January to $34{ }^{\circ} \mathrm{C}$ in August (annual mean value: $18^{\circ} \mathrm{C}$ ). The annual precipitation ranges from $450-600 \mathrm{~mm}$, with most rain in November and December. The coastal area receives about $100 \mathrm{~mm}$ more rain than the inland area. Periods of summer drought easily last for more than two months, even though some alleviation may come from the humid atmosphere close to the coast. This dry season generally starts by the end of April or early May and extends until October (Aafi et al. 2005a). High summer temperatures and extreme dryness of the sandy top soils contribute to a rapid oxidation of all organic material at the surface whenever soils are bare or lose their cover, leading to very low levels of soil organic matter (Lepoutre 1967). As a result of these differences in microclimatic conditions, the western part of the Mamora forest is characterized by a sub humid climate with warm winters, while the eastern part is semi-arid with temperate winters (Benabid \& Fennane 1994).

Mamora forest has a total surface area of 133000 ha (Laaribya 2006), of which around 60000 ha has cork oak as the main species, together with an endemic pear (Pyrus mamorensis Trab.) appearing in little thickets, but never in full stands. The mastic tree (Pistacia lentiscus L.), wild olive (Olea europaea L. subsp. oleaster [Hoffmans \& Link] Negodi) and mock privet (Phillyrea latifolia L.) can be found, but remain uncommon. The understorey vegetation, when it is dense, is composed of flax-leaf broom (Genista linifolia L.) and Thymelaea lythroides (Barr. et Murbeck) in the western part of the forest and of rock rose (Halimium halimifolium [L.] Willk.) in the eastern part. These shrubs can form dense maquis vegetation that can almost completely eliminate the other shrub species (Aafi 2007). Dense stands (density >
200 trees ha-1) make up $7 \%$ of the cork oak surface area, moderately dense stands (100-200 trees ha ${ }^{-1}$ ) account for $29 \%$, and stands with low stocking levels ( $<100$ trees $\mathrm{ha}^{-1}$ ) make up the remaining $64 \%$ (Aafi et al. 2008). Besides forest stands, open areas occupy about $5.6 \%$ of the surface area in the Mamora forest (Aafi et al. 2008). These include degraded cork forests and natural clearings when soil conditions do not enable trees to grow (i.e., shallow soils close to the clayey subsoil, resulting in high water tables in winter).

Since 1914, the forest has been subjected to several management programs, including restoration attempts, introduction of exotic tree species (e.g., Eucalptus camaldulensis Dehnh. and Pinus pinaster Ait. in Soland var. atlantica), and management schemes which aim to implicate local users and to regenerate cork oak by seeding or replanting. Despite all these efforts, the actual cork oak stands represent only half of the former area and many stands have fairly low stocking levels (i.e., lower than 150-200 individuals per ha). Most remaining stems have grown tall and the coppice can be characterized as overstood; some even have several large stems on one stool.

\section{Sampling strategy}

A total of 21 stands were investigated in this study, all of them being in the western part of the forest (cantons $A$ and $B$ of the forest, between $6^{\circ} 21^{\prime}$ and $6^{\circ} 44^{\prime} \mathrm{W}$ and between $33^{\circ} 59^{\prime}$ and $34^{\circ} 18^{\prime} \mathrm{N}-$ see Fig. S1 in Appendix 1). All of these stands have not experienced any cut for 63 years and the total area with cork oak in these cantons is around 25000 ha. The soils studied are sandy, devoid of rock and with a fine fraction $(<2 \mathrm{~mm})$ in the order of $100 \%$ as shown by the particle size analysis. A summary description is presented in Tab. 1. In addition to forest stands, one open area was also included in the investigation, so as to be able to compare the soil carbon storage in an area deforested for a long time. In each stand, all trees present in a central area of 1 ha were measured (tree girth at breast height: $C_{130}$ in $\mathrm{cm}$ ). This survey of 4963 trees enabled us to establish the diameter distribution in our study area. We selected individual trees for tree volume assessments and regression equations based on this inventory. A first allometric relationship was built between tree height and $C_{130}$ using 117 trees representing the range of tree size encountered in the whole study region (Fig. S2 in Appendix 1). Out of these 117 trees, we selected 34 trees which were representative of our $21 \mathrm{stu}$ died stands. As Moroccan law does not allow trees to be sampled destructively in the protected cork oak stands in Mamora, we used an indirect method of geometrical cubing, considering that one stem belonged to several successive geometrical types (Pardé 1966). Tree volumes were thus determined by cubing all the subsequent boles. To this end, all of the 34 trees were 
Tab. 1 - Summary description of the study area and distribution of the stands per density class. (D): range of average tree diameters (at $130 \mathrm{~cm}$ ) per stand using quadratic means to compute the mean diameter for each stand; (BA): Basal area; (a): of each density class in the cantons A and B, after Aafi et al. 2008; (b): data from this study.

\begin{tabular}{lccccc}
\hline Stands & $\begin{array}{c}\text { Density class } \\
\left(\text { stems ha }^{-1}\right)\end{array}$ & $\begin{array}{c}\text { Surface area in } \\
\text { Mamora (ha) }\end{array}$ & $\begin{array}{c}\text { Soil pH }^{\mathrm{b}} \\
\left(\mathbf{H}_{2} \mathbf{O}\right)\end{array}$ & $\begin{array}{c}\mathrm{D}^{\mathrm{b}} \\
(\mathbf{m})\end{array}$ & $\begin{array}{c}\mathrm{BA}^{\mathrm{b}} \\
\left(\mathbf{m}^{2} \mathbf{h a}^{-1}\right)\end{array}$ \\
\hline Open area & - & 7350 & $6.1-6.9$ & - & - \\
S1-S6 $(\mathrm{n}=6)$ & $<100$ & 37621 & $4.9-6.4$ & $2.7-4.4$ & $5.6-15.1$ \\
S7-S12 $(\mathrm{n}=6)$ & $100-200$ & 16665 & $4.9-6.4$ & $3.1-4.3$ & $7.8-14.4$ \\
S13-S21 $(\mathrm{n}=9)$ & $>200$ & 4110 & $4.9-6.4$ & $3.4-5.8$ & $9.0-26.7$ \\
\hline
\end{tabular}

accessed by climbing and the height and circumference of the boles were measured at $30 \mathrm{~cm}, 130 \mathrm{~cm}$ and then for each of the boles up to the height where the stem diameter reached $10 \mathrm{~cm}$. The length and circumference of the branches were measured as well on each bole of $1 \mathrm{~m}$ length until the cutting diameter of $10 \mathrm{~cm}$ was reached.

For the understorey vegetation, in each central area of 1 ha of each stand, 25 squares of $1 \mathrm{~m}^{2}$ were established at random. In each of these squares, the entire aboveground tissue of understorey species was harvested. Plants were weighed per species after drying at $65^{\circ} \mathrm{C}$ to constant weight. Finally, the plant material was cut into fine pieces and then ground before laboratory analyses. In order to estimate belowground biomass of the understorey vegetation, we harvested 10 individuals per understorey species completely (both aboveground and belowground). This was used to compute an average root/shoot ratio. The main understorey species were Chamaerops humilis, Thymelaea lythroides and Genista linifolia.

For the study of litter and soil, sampling was restricted to a plot of 0.25 ha located in the central 1 ha area used to survey the trees. This 0.25 ha plot was further subdivided into 25 subplots of $100 \mathrm{~m}^{2}$ each. In the middle of each one of these 25 subplots, a $1 \mathrm{~m}^{2}$ square was established for litter collection, followed by soil sampling down to a soil depth of 1 meter. The depth of 1 meter was based on preliminary observations showing that organic matter was mostly located in the uppermost horizons of the soil. For the litter, all of the litter from each $1 \mathrm{~m}^{2}$ square was collected, dried and weighed. For the soil, a soil core was taken and divided into five soil layers (0-20, 20-40, 40-60, 60-80, 80-100 cm). Both for the litter and the five soil depth layers, the 25 individual samples for the 0.25 ha plot were used to compose one composite sample per layer for the 0.25 ha plot (equal weight basis). These composite samples were oven-dried at $65^{\circ} \mathrm{C}$ to constant weight, then ground and sieved at $2 \mathrm{~mm}$. Soil bulk density was assessed on one soil pit per 0.25 ha stand using density cylinders $(\varnothing 5.5 \mathrm{~cm}$, length $10.5 \mathrm{~cm})$. To this end, a cylinder was inserted horizontally into each soil layer from the pit wall with a rubber hammer. The cylinder was then gently removed with a knife and excess soil was discarded. The density cylinders were emptied into sample bags and the weight was assessed for each sample after drying at 65 ${ }^{\circ} \mathrm{C}$ to constant weight, from which the soil bulk density $\left(\mathrm{kg} \mathrm{dm}^{-3}\right)$ was calculated.

For the soil samples, the organic carbon content was assessed by the acid oxidation method (Walkley \& Black 1934). It has been suggested that the above method used to determine soil carbon can lead to underestimates of organic carbon contents, but this bias has been shown to be lower for soils under dry conditions (Meersmans et al. 2009, Tirez et al. 2014). In order to check this potential bias, we first established a representative subset of soil samples and compared the Walkley \& Black's method with the method by Anne (1945) and a method based on loss on ignition $\left(600^{\circ} \mathrm{C}\right.$ for four hours). The three methods gave very comparable results for our conditions and consequently, for the entire set of soil method on a routine basis. For organic carbon analysis of the litter samples and plant samples, an aliquot of $2 \mathrm{~g}$ was combusted at $600{ }^{\circ} \mathrm{C}$ for four hours in a muffle furnace to estimate the organic matter content. The amount of carbon was then computed by dividing the organic matter content by a coefficient of 1.73 (after Bernoux et al. 2013).

\section{Data handling and statistics}

First, regression equations were used to estimate the aboveground tree volume and for this the circumference at breast height $\left(C_{130}\right.$ in $\left.\mathrm{cm}\right)$ was used (Rapp et al. 1999, Davi et al. 2005). The equations were performed with SAS ${ }^{\top M}$ (JMP ${ }^{\circ}$ 9.0.0 - SAS Institute, Cary, NC, USA) and included polynomial and logarithmic relationships with one (circumference $C_{130}$ ) or two (circumference $C_{130}$ and height $H$ ) entries (see Tab. $\mathrm{S}_{2}$ in Appendix 1 for the equations tested for the volume estimations). The choice of the final model was based on the following parameters: coefficient of determination $\left(R^{2}\right)$, residual standard error (Sy, $\left.x\right)$, Fisher's F-test and Furnival's indice (IF), mean relative errors for cubing (e) and standard deviation of error distribution for cubing (Se). The models were adjusted for the tree volume of wood, thick branches $(\varnothing>$ $10 \mathrm{~cm}$ ) and cork using the data from the 34 measured trees. In total eight equations samples, we applied the Walkley \& Black's were tested (Tab. S1 in Appendix 1). The statistical analysis of these models showed that the logarithmic models performed better, and furthermore they have the advantage of being easily transferable to other contexts and comparable to other studies. Therefore, in our study, the models retained were (eqn. 1):

$$
V_{\text {tree }}=0.6 C^{2.18}
$$

for the one entry model, and for the two entry model (eqn. 2):

$$
V_{\text {tree }}=0.25 C^{2.088} H^{0.362}
$$

where $V_{\text {tree }}$ is the tree volume (in $\mathrm{m}^{3}$ ), $C$ the circumference at $130 \mathrm{~cm}$ (in $\mathrm{m}$ ) and $H$ the tree height (in $\mathrm{m}$ ). Model performance for both equations was good and comparable (see Tab. S2 in Appendix 1 for the summary parameters for all eight equations, and in Fig. $\mathrm{S}_{3}$ in Appendix 1 for the residuals of eqn. 1 and eqn. 2).We finally preferred to retain the equation using only the circumference (eqn. 1) as the tree heights could not be assessed on a routine basis for all trees in all of the stands. As destructive measurements in the stand were not possible, we could not sample cork separately from wood. Likewise, we were unable to consider the small branches and leaves directly by the tree climbing and cubing method. Therefore, we chose to use an equation for cork biomass from the work by Makhloufi et al. (2008) for nearby Quercus suber forests on hilly sites north of the study area in Morocco, and equations by Ruiz-Peinado et al. (2012) from comparable ecoystems in Spain for the branches beyond our threshold of $10 \mathrm{~cm}$ diameter as well as foliage. The diameter and tree height ranges used in these two studies were well matched with those of this investigation. In particular, for the cork bark material we used the equation from Makhloufi et al. (2008) - eqn. 3:

$$
V_{\text {cork }}=0.0151 \cdot\left(C_{130}\right)^{1.9827}
$$

and (eqn. 4):

$$
V_{\text {stem-without-bark }}=V_{\text {tree }}-V_{\text {cork }}
$$

where $V_{\text {cork }}$ is the volume of the cork (equation from Makhloufi et al. 2008, in $\mathrm{dm}^{3}$ ), $C_{130}$ the circumference at $130 \mathrm{~cm}$ (in $\mathrm{cm}$ ), $V_{\text {stem-without-bark }}$ is the tree volume without bark $\left(\mathrm{m}^{3}\right)$, and $V_{\text {tree }}$ the tree volume of wood, thick branches and cork (in $\mathrm{m}^{3}$ from eqn. 1). The corresponding biomass values for both compartments were then computed as follows (eqn. 5):

$$
B_{\text {cork }}=V_{\text {cork }} \cdot D
$$

and (eqn. 6):

$$
B_{\text {stem-without-bark }}=V_{\text {stem-without bark }} \cdot D
$$

where $B_{\text {cork }}$ the biomass of cork (kg), $V_{\text {cork }}$ 
the volume of cork $\left(\mathrm{m}^{3}\right), B_{\text {stem-without-bark }}$ is the biomass of the stem and coarse branches without bark (kg), $V_{\text {stem-without bark }}$ the volume of the stem without bark $\left(\mathrm{m}^{3}\right)$ and $D$ the specific tissue density (Tab. $2, \mathrm{~kg} \mathrm{~m}^{-3}$ ). For the medium branches and small branches including their foliage, we used the eqn. 7 and eqn. 8 from Ruiz-Peinado et al. (2012):

$$
B_{\text {medium-branch }}=0.127 \cdot D_{130} \cdot H
$$

and (eqn. 8):

$$
B_{\text {small-branch-foliage }}=0.0463 \cdot D_{130} \cdot H
$$

where $B_{\text {medium-branch }}$ is the biomass of medium branches (diameter 2-10 cm) in $\mathrm{kg}$, $B_{\text {small-branch-foliage the biomass of small bran- }}$ ches ( $<2 \mathrm{~cm}$ diameter) and supported foliage $(\mathrm{kg}), D_{130}$ the diameter at breast height (in $\mathrm{cm}$ ) and $H$ the tree height (in $\mathrm{m}$ ). For trees whose height was not measured directly, tree heights were derived from the relationship between $H$ and $C_{130}$ (Fig. S2 in Appendix 1). Then we computed tree biomass for all the aboveground tissues (eqn. 9) on an individual tree basis by adding the biomass of medium branches, small branches and foliage (from eqn. 7 and eqn. 8) to the biomass of trunk and branches without cork and the biomass of this cork (from eqn. 5 and eqn. 6 ), as follows (eqn. 9):

$$
\begin{aligned}
B_{\text {tree-ABG }}= & B_{\text {stem-without-bark }}+B_{\text {cork }}+ \\
& B_{\text {medium-branch }}+B_{\text {small-branch-foliage }}
\end{aligned}
$$

where $B_{\text {tree-ABC }}$ is the tree biomass (in $\mathrm{kg}$ ), $B_{\text {stem-without-bark }}$ the biomass of the stem and coarse branches without bark (kg), $B_{\text {cork }}$ the biomass of cork (kg), $B_{\text {medium-branch is the }}$ biomass of medium branches (kg) and $B_{\text {small-branch-foliage }}$ the biomass of small and supported foliage $(\mathrm{kg})$. Then for the carbon contained in the aboveground biomass of the cork oak trees we applied the following equation (eqn. 10):

$$
C_{s t-A B G}=\sum 10^{-3} \cdot\left(B_{\text {tree }-A B G} \cdot C_{\text {conc }-A B G}\right)
$$

where $C_{\text {st-ABG }}$ is the carbon stock (in $\mathrm{kg}$ ) for an individual tree, $10^{-3}$ is a conversion factor, $B_{\text {tree-ABC }}$ is the aboveground biomass (in $\mathrm{kg}$ ) for the respective components (i.e., cork, stem without bark, medium-branches, small branches and foliage) and $C_{\text {conc- }}$ ${ }_{A B C}$ is the mean carbon concentration of the respective aboveground tissues (in $\mathrm{g} \mathrm{kg}^{-1}$ values from Tab. 2). For the carbon content in the belowground tissues of trees, we used the equation developed by Ruiz-Peinado et al. (2012) to estimate the root biomass, and multiplied this by the mean carbon concentration (eqn. 11):

$$
B_{\text {tree }-B L G}=0.0829 \cdot D_{130}^{2}
$$

where $B_{\text {tree-BLC }}$ is the belowground biomass of an individual tree in $\mathrm{kg}$ and $D_{130}$ the diameter at breast height $(130 \mathrm{~cm})$ in $\mathrm{cm}$. Combined with the mean carbon concentration, this can be written as (eqn. 12):

$$
C_{s t-B L G}=10^{-3} \cdot B_{\text {tree }-B L G} \cdot C_{\text {conc }-B L G}
$$

where $C_{\text {stBLC }}$ is the carbon stock in the belowground tissues of an individual tree (in $\mathrm{kg}$ ), $10^{-3}$ is a conversion factor and $C_{\text {conc- }}$ BLC the average carbon concentration in belowground tissues (in $\mathrm{g} \mathrm{kg}^{-1}$ - Tab. 2).

Then for each stand, the total carbon content in aboveground ( $\left.C_{\text {st-ABG-Stand }}\right)$ and belowground ( $\left.C_{\text {st-BLG-Stand }}\right)$ tissues was calculated as the sum of the carbon contents of all the individual trees (eqn. 13):

$$
C_{s t-Q U E R C U S}=\sum\left(C_{s t-A B G}+C_{s t-B L G}\right)
$$

where $C_{\text {st-Quercus }}$ is the total carbon content in the Quercus suber trees of each entire stand $\left(\mathrm{Mg} \mathrm{ha}^{-1}\right)$, and $C_{\text {st-ABG }}$ and $C_{\text {st-BLC }}$ are the carbon contents in aboveground and belowground parts of each tree $(\mathrm{kg})$, respectively.

For the understorey species, firstly dry weights per species for the fully harvested aboveground tissues were assessed after drying. Based on specific root/shoot values (see above), we estimated the corresponding root biomass. Then average biomass values were computed for each understorey species at the stand scale and multi-

Tab. 2 - Specific tissue density and mean carbon concentration of the tissues.

\begin{tabular}{llcc}
\hline Species & $\begin{array}{l}\text { Plant } \\
\text { component }\end{array}$ & $\begin{array}{c}\text { Mean carbon } \\
\text { concentration } \\
\left(\mathbf{g ~ k g}^{-1}\right)\end{array}$ & $\begin{array}{c}\text { Specific tissue } \\
\text { density }\left(\mathbf{k g ~ m}^{-3}\right)\end{array}$ \\
\hline $\begin{array}{l}\text { Quercus } \\
\text { suber }\end{array}$ & $\begin{array}{l}\text { Wood of the trunk and thick } \\
\text { branches }(\varnothing>10 \mathrm{~cm})\end{array}$ & 560 & 830 \\
& Medium branches $(2 \leq \emptyset \leq 10 \mathrm{~cm})$ & 540 & - \\
& Small branches $(\varnothing<2 \mathrm{~cm})$ & 530 & - \\
& Foliage & 520 & - \\
& Cork & 560 & 540 \\
& Roots & 540 & - \\
Thymelea & Understorey & - & - \\
lythroides & Belowground & 520 & - \\
Genista & Aboveground & 450 & - \\
linifolia & Belowground & 540 & - \\
Chamaerops & Aboveground & 530 & - \\
humilis & Belowground & 530 & - \\
\hline
\end{tabular}

plied by the average carbon concentration for each component to assess the carbon storage of the understorey (eqn. 14):

$$
\begin{aligned}
& C_{\text {st-Understorey }}=\sum 10^{-3} \cdot \\
& \quad\left[\left(B_{A B G-s p 1} \cdot C_{c o n c}\right)+\left(B_{B L G-s p 1} \cdot C_{c o n c}\right)\right]
\end{aligned}
$$

where $C_{\text {st-Understorey }}$ is the carbon stock in the understorey vegetation ( $\left.\mathrm{Mg} \mathrm{ha}^{-1}\right), 10^{-3}$ is a conversion factor, $B_{\mathrm{ABC}-\mathrm{sp} 1}$ is the biomass of the aboveground tissues of species 1 (kg $\left.\mathrm{ha}^{-1}\right), B_{\mathrm{BLC}-\mathrm{sp1}}$ is the biomass of the belowground tissues of species $1\left(\mathrm{~kg} \mathrm{ha}^{-1}\right)$ and $C_{\text {conc }}$ the average carbon concentration for the respective tissues (specific to species and component - $\mathrm{g} \mathrm{kg}^{-1}$ ).

For the carbon stocks in the litter we used the following equation (eqn. 15):

$$
C_{\text {st-LITTER }}=\sum 10^{-3} \cdot\left(M_{\text {LITTER }} \cdot C_{\text {conc-LITTER }}\right)
$$

where $C_{\text {st-LITTER }}$ is the carbon stock $\left(\mathrm{Mg} \mathrm{ha}^{-1}\right)$, $10^{-3}$ is a conversion factor, $M_{\text {LITTER }}$ is the dry mass $\left(\mathrm{g} \mathrm{m}^{-2}\right)$ obtained from the harvested litter for each $1 \mathrm{~m}^{2}$ square, and $C_{\text {conc-LITTER }}$ the mean carbon concentration for each plot $\left(\mathrm{g} \mathrm{kg}^{-1}\right)$. Carbon stocks in the different soil horizons were computed using three parameters (Belkacem et al. 1998, Peng et al. 2000, Evans et al. 2001, Cerri et al. 2007 eqn. 16):

$C_{\text {st-SOLL-layer }}=0.1 \cdot$ Thickness $_{\text {Layer }} \cdot B D \cdot C_{\text {conc-SOIL }}$

where $C_{\text {st-sol-layer }}$ is the carbon content in a given soil layer ( $\left.\mathrm{Mg} \mathrm{ha}^{-1}\right), 0.1$ is a conversion factor, Thickness Layer $_{\text {is }}$ is the thickness of this soil layer $(\mathrm{cm}), B D$ is the bulk soil density ( $\mathrm{g}$ $\mathrm{cm}^{-3}$ ) and $C_{\text {conc-soll }}$ is the carbon concentration $\left(\mathrm{g} \mathrm{kg}^{-1}\right)$. Then, for each plot the total carbon content in the soil down to $1 \mathrm{~m}$ of soil depth was calculated as the sum of the carbon contents of all five soil depth layers (eqn. 17):

$$
C_{s t-S O I L}=\sum\left(C_{s t-\text { soil-layer }}\right)
$$

where $C_{\text {st-soll }}$ is the carbon content of the soil down to $1 \mathrm{~m}$ of soil depth $\left(\mathrm{Mg} \mathrm{ha}^{-1}\right)$ and $C_{\text {st-soillayer }}$ is the carbon content of individual layers $\left(\mathrm{Mg} \mathrm{ha}^{-1}\right)$. In order to evaluate the carbon storage in our ecosystem, relationships between the overall parameters of stand density and basal area on the one hand, and carbon stocks in the trees ( $C_{\text {st. }}$ QuerCus $)$, the understorey $\left(C_{\text {St-UnDERSTOREY }}\right)$, the soil $\left(C_{\text {st-SOIL }}\right)$ and the litter $\left(C_{\text {st-LITTER }}\right)$ on the other hand, were explored.

\section{Results}

\section{Carbon storage in cork oak trees}

The structure of the cork oak stands considered in this work was regular with a modus occuring in the $70 \mathrm{~cm}$ circumference class, but no stems had a circumference less than $30 \mathrm{~cm}$. This is representative of the overall structure of cork oak forest in the Mamora region. Small circumference individuals nearly only occur in regeneration plots protected by a fence, while very large individuals with diameters beyond 
Tab. 3 - Biomass and carbon stocks in the cork oak stands. (D): stand density of the cork oak stand (stem ha $\left.{ }^{-1}\right)$; (BA): basal area of the stand $\left(\mathrm{m}^{2}\right.$ ha $\left.\mathrm{C}^{-1}\right)$; (ABG): aboveground tissues; (BLG): belowground tissues; (C): carbon stock in the cork; (TTB): carbon stock in trunk and thick branches $(\varnothing>10 \mathrm{~cm})$ without cork; $(\mathrm{MB})$ : carbon stock in medium branches $(2 \leq \varnothing \leq 10 \mathrm{~cm})$; (SBF): carbon stock in small branches $(\varnothing<2 \mathrm{~cm})$ and foliage; $(\Sigma)$ : sum of carbon in the aboveground tissues.

\begin{tabular}{|c|c|c|c|c|c|c|c|c|c|c|c|c|}
\hline \multirow{3}{*}{$\begin{array}{l}\text { Density class } \\
\left(\text { stem ha }^{-1}\right)\end{array}$} & \multirow{3}{*}{ Stand } & \multirow{3}{*}{$\begin{array}{c}\text { BA } \\
\left(m^{2} h^{-1}\right)\end{array}$} & \multicolumn{3}{|c|}{ Stand biomass $\left(\mathrm{Mg} \mathrm{ha}^{-1}\right)$} & \multicolumn{7}{|c|}{ Stand carbon $\left(\mathrm{Mg} \mathrm{ha}^{-1}\right)$} \\
\hline & & & \multirow{2}{*}{ ABG } & \multirow{2}{*}{ BLG } & \multirow{2}{*}{ Total } & \multicolumn{5}{|c|}{ ABG } & \multirow{2}{*}{ BLG } & \multirow{2}{*}{ Total } \\
\hline & & & & & & C & TTB & MB & SBF & $\Sigma$ & & \\
\hline \multirow{7}{*}{$D<100$} & S1 & 8.04 & 54.63 & 8.49 & 63.12 & 4.2 & 23.5 & 2.1 & 0.7 & 30.5 & 4.6 & 35.1 \\
\hline & S2 & 15.14 & 104.00 & 15.99 & 119.99 & 8.0 & 45.0 & 3.7 & 1.3 & 58.0 & 8.6 & 66.6 \\
\hline & S3 & 8.21 & 54.24 & 8.67 & 62.91 & 4.3 & 22.8 & 2.3 & 0.8 & 30.2 & 4.7 & 34.9 \\
\hline & S4 & 5.63 & 38.13 & 5.95 & 44.08 & 3.0 & 16.3 & 1.5 & 0.5 & 21.3 & 3.2 & 24.5 \\
\hline & S5 & 12.6 & 86.23 & 13.31 & 99.54 & 6.6 & 37.2 & 3.1 & 1.1 & 48.0 & 7.2 & 55.3 \\
\hline & S6 & 7.15 & 48.41 & 7.56 & 55.97 & 3.8 & 20.7 & 1.8 & 0.7 & 27.0 & 4.1 & 31.1 \\
\hline & Mean & - & 64.27 & 10.00 & 74.27 & 5.0 & 27.6 & 2.4 & 0.9 & 35.8 & 5.4 & 41.2 \\
\hline \multirow{7}{*}{$100 \leq D \leq 200$} & S7 & 9.75 & 63.14 & 10.30 & 73.44 & 5.2 & 26.1 & 2.9 & 1.0 & 35.2 & 5.6 & 40.8 \\
\hline & S8 & 7.77 & 50.88 & 8.21 & 59.09 & 4.1 & 21.2 & 2.2 & 0.8 & 28.3 & 4.4 & 32.8 \\
\hline & S9 & 9.94 & 64.39 & 10.50 & 74.89 & 5.3 & 26.6 & 3.0 & 1.0 & 35.9 & 5.7 & 41.6 \\
\hline & S10 & 8.04 & 72.55 & 11.69 & 84.24 & 5.9 & 30.3 & 3.1 & 1.1 & 40.4 & 6.3 & 46.7 \\
\hline & S11 & 9.59 & 63.59 & 10.13 & 73.72 & 5.1 & 26.8 & 2.7 & 0.9 & 35.5 & 5.5 & 40.9 \\
\hline & S12 & 14.45 & 97.62 & 15.26 & 112.88 & 7.6 & 41.7 & 3.8 & 1.3 & 54.4 & 8.2 & 62.6 \\
\hline & Mean & - & 68.70 & 11.02 & 79.71 & 5.5 & 28.8 & 2.9 & 1.0 & 38.3 & 5.9 & 44.2 \\
\hline \multirow{10}{*}{$D>200$} & S13 & 12.11 & 103.56 & 16.97 & 120.53 & 8.5 & 42.6 & 4.9 & 1.7 & 57.7 & 9.2 & 66.9 \\
\hline & S14 & 18.56 & 117.78 & 19.67 & 137.45 & 9.9 & 47.6 & 6.0 & 2.1 & 65.6 & 10.6 & 76.2 \\
\hline & S15 & 24.3 & 154.32 & 25.66 & 179.98 & 12.9 & 62.6 & 7.7 & 2.7 & 85.9 & 13.9 & 99.9 \\
\hline & S16 & 16.57 & 103.28 & 17.50 & 120.78 & 8.8 & 41.1 & 5.6 & 2.0 & 57.5 & 9.5 & 67.0 \\
\hline & S17 & 15.49 & 100.01 & 16.36 & 116.37 & 8.2 & 41.2 & 4.7 & 1.7 & 55.8 & 8.8 & 64.5 \\
\hline & S18 & 26.73 & 170.19 & 28.23 & 198.42 & 14.2 & 69.1 & 8.5 & 3.0 & 94.8 & 15.2 & 110.0 \\
\hline & S19 & 22.29 & 141.11 & 23.54 & 164.65 & 11.8 & 57.1 & 7.1 & 2.5 & 78.5 & 12.7 & 91.3 \\
\hline & S20 & 21.32 & 133.31 & 22.52 & 155.83 & 11.4 & 53.2 & 7.1 & 2.5 & 74.2 & 12.2 & 86.4 \\
\hline & S21 & 8.99 & 57.53 & 9.56 & 67.09 & 4.8 & 23.3 & 2.9 & 1.0 & 32.0 & 5.2 & 37.2 \\
\hline & Mean & - & 120.12 & 20.00 & 140.12 & 10.1 & 48.6 & 6.0 & 2.1 & 66.9 & 10.8 & 77.7 \\
\hline
\end{tabular}

$200 \mathrm{~cm}$ are uncommon (Fig. S4 in Appendix 1). The biomass at the stand scale ranged from 64.3 to 120.1 ha $^{-1}$ for aboveground tissues and 10-20 $\mathrm{Mg}^{-1} \mathrm{~h}^{-1}$ for belowground tissues (Tab. 3). The overall averages were $89.5 \mathrm{Mg} \mathrm{ha} \mathrm{h}^{-1}$ for aboveground biomass (range of 38.1-170.2 $\mathrm{Mg} \mathrm{ha}^{-1}$ ) and $14.6 \mathrm{Mg}$ $\mathrm{ha}^{-1}$ for belowground biomass (range $5.9^{-}$ 28.2 Mg ha-1 - Tab. 3). This represented average carbon stocks of $35.8-66.9 \mathrm{Mg} \mathrm{ha}^{-1}$ for aboveground tissues and 5.4-10.8 Mg $\mathrm{ha}^{-1}$ for belowground tissues (Tab. 3). The lowest value for carbon stocks occurred in the rather open stand $\mathrm{S}_{4}\left(21.3 \mathrm{Mg} \mathrm{ha}^{-1}\right.$ aboveground, 3.2 $\mathrm{Mg} \mathrm{ha}^{-1}$ belowground), while the highest value was recorded in the dense stand $\mathrm{S} 18$ ( $94.8 \mathrm{Mg} \mathrm{ha}^{-1}$ aboveground, 15.2 $\mathrm{Mg} \mathrm{ha}^{-1}$ belowground). For the aboveground tissues, on average $14.7 \%$ of all stored carbon was found within the cork, $74.1 \%$ in the trunk and thick branches, $8.3 \%$ in medium branches and $2.9 \%$ in small branches and foliage (Tab. 3). The belowground biomass represented around $14 \%$ of total stand biomass. Fig. 1a shows the relationship between stand density and the total carbon stocks per stand present in the aboveground tissues of the cork oak trees $\left(C_{\text {st-ABG-Stand }}\right)$. The correlation was fairly strong $\left(R^{2}=0.78\right)$. Despite some dimensional variation between individual trees, having a higher tree density correlated well with the total carbon stocks in the aboveground tissues. Had there been very young (small diameter, small height and small biomass) dense stands in Mamora forest, the relationship might not have been valid for such stands. The relationship can thus be used under our forest conditions (stand structure, age, dimensions) to estimate carbon storage in the aboveground parts of the cork oak trees.

\section{Carbon storage in the understorey of} the cork oak stands

Understorey vegetation was present in variable quantities in the 21 stands investigated, i.e., very degraded stands where understorey was nearly absent co-occurred with stands still having a fairly well developed understorey. Over larger areas typically the understorey vegetation was either nearly absent or rather homogenous as distribution and dimensions. Three species were dominant in the inventory, and

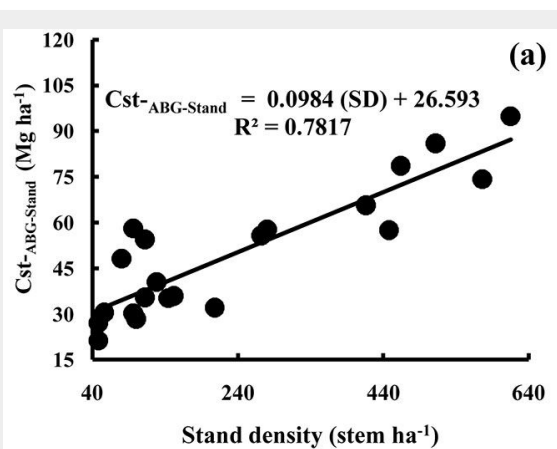

Fig. 1 - Relationships between stand density and total carbon stocks per stand present in the aboveground tissues. Diagrams refer to: (a) Quercus suber; (b) understorey. ( $\left.C_{\text {st_AB__stand }}\right)$ : total carbon stock per stand present in the aboveground tissues of the cork oak trees $\left(\mathrm{Mg} \mathrm{ha}^{-1}\right)$; $\left(C_{\text {st understorey } \mathrm{ABC}}\right)$ : total carbon stock per stand present in the aboveground tissues of understorey (Mg ha $\left.{ }^{-1}\right)$; (SD): stand density (stem ha-1).

these represented in total between 0.5 and $4.8 \mathrm{Mg} \mathrm{ha}^{-1}$ of biomass (Tab. 4), with an average of $1.6 \mathrm{Mg} \mathrm{ha}^{-1}$. The average was $0.85 \mathrm{Mg} \mathrm{ha}^{-1}$ for the densest stands and $2.62 \mathrm{Mg} \mathrm{ha}^{-1}$ for the most open stands. Flaxleaf broom was the species contributing most to the total biomass. Understorey represented 0.4 to $2.3 \%$ of total stand aboveground biomass for cork oak stands with stand densities over 200 stems ha $^{-1}$ or less than 100 stems $\mathrm{ha}^{-1}$, respectively. The respective carbon stocks in the understorey (aboveground and belowground) ranged from 0.3 to $2.9 \mathrm{Mg} \mathrm{ha}^{-1}$ with an average of $1.0 \mathrm{Mg} \mathrm{ha}^{-1}$ (Tab. 4). Fig. 1b shows the relationship between stand density and the total carbon stocks per stand present in 
Tab. 4 - Biomass and carbon stocks in the understorey of the cork oak stands. (ABG): aboveground tissues; (BLG): belowground tis sues; (D): stand density of the cork oak stand (stem ha-1); (*): belowground biomass was computed with a mean root : shoot ratio $(\mathrm{R} / \mathrm{S})$ established on 10 uprooted individuals for each main understory species, yielding values of R/S of $35 \%$ for G. linifolia, $49 \%$ for T. lytrhoides and $93 \%$ for C. humilis.

\begin{tabular}{|c|c|c|c|c|c|c|c|c|c|}
\hline \multirow{2}{*}{$\begin{array}{l}\text { Density Class } \\
\left(\text { stem ha }^{-1} \text { ) }\right.\end{array}$} & \multirow[b]{2}{*}{ Stand } & \multicolumn{4}{|c|}{ Total biomass ABG + BLG $\left(\mathrm{Mg} \mathrm{ha}^{-1}\right)^{*}$} & \multicolumn{4}{|c|}{ Total carbon ABG + BLG $\left(\mathrm{Mg} \mathrm{ha}^{-1}\right)$} \\
\hline & & $\begin{array}{l}\text { Genista } \\
\text { linifolia }\end{array}$ & $\begin{array}{l}\text { Thymelaea } \\
\text { lythroides }\end{array}$ & $\begin{array}{c}\text { Chamearops } \\
\text { humilis }\end{array}$ & $\begin{array}{c}\Sigma \\
\text { understory }\end{array}$ & $\begin{array}{l}\text { Genista } \\
\text { linifolia }\end{array}$ & $\begin{array}{l}\text { Thymelea } \\
\text { lythroides }\end{array}$ & $\begin{array}{c}\text { Chamearops } \\
\text { humilis }\end{array}$ & $\begin{array}{c}\Sigma \\
\text { understory }\end{array}$ \\
\hline \multirow[t]{7}{*}{$\mathrm{D}<100$} & S1 & 2.50 & 1.62 & 0.71 & 4.83 & 1.34 & 1.14 & 0.39 & 2.87 \\
\hline & S2 & 1.49 & 0.97 & 0.43 & 2.89 & 0.80 & 0.68 & 0.23 & 1.72 \\
\hline & S3 & 1.29 & 0.83 & 0.37 & 2.49 & 0.69 & 0.59 & 0.20 & 1.48 \\
\hline & S4 & 0.97 & 0.63 & 0.28 & 1.87 & 0.52 & 0.44 & 0.15 & 1.11 \\
\hline & S5 & 1.09 & 0.70 & 0.31 & 2.10 & 0.58 & 0.50 & 0.17 & 1.25 \\
\hline & S6 & 0.80 & 0.52 & 0.23 & 1.55 & 0.43 & 0.36 & 0.13 & 0.92 \\
\hline & Mean & 1.36 & 0.88 & 0.39 & 2.62 & 0.73 & 0.62 & 0.21 & 1.56 \\
\hline \multirow[t]{7}{*}{$100 \leq D \leq 200$} & S7 & 0.00 & 1.29 & 0.50 & 1.79 & 0.00 & 0.91 & 0.27 & 1.18 \\
\hline & S8 & 0.00 & 1.62 & 0.62 & 2.24 & 0.00 & 1.14 & 0.34 & 1.49 \\
\hline & S9 & 0.94 & 0.00 & 0.97 & 1.92 & 0.51 & 0.00 & 0.53 & 1.04 \\
\hline & $\mathrm{S} 10$ & 1.47 & 0.00 & 0.72 & 2.19 & 0.79 & 0.00 & 0.39 & 1.18 \\
\hline & S11 & 0.73 & 0.00 & 0.36 & 1.08 & 0.39 & 0.00 & 0.20 & 0.59 \\
\hline & $\mathrm{S} 12$ & 0.92 & 0.00 & 0.45 & 1.37 & 0.49 & 0.00 & 0.25 & 0.74 \\
\hline & Mean & 0.68 & 0.49 & 0.60 & 1.77 & 0.36 & 0.34 & 0.33 & 1.04 \\
\hline \multirow[t]{10}{*}{$D>200$} & $\mathrm{~S} 13$ & 0.08 & 0.92 & 0.15 & 1.15 & 0.04 & 0.65 & 0.08 & 0.78 \\
\hline & S14 & 0.05 & 0.56 & 0.09 & 0.70 & 0.03 & 0.39 & 0.05 & 0.47 \\
\hline & S15 & 0.07 & 0.83 & 0.14 & 1.04 & 0.04 & 0.58 & 0.08 & 0.70 \\
\hline & S16 & 0.06 & 0.72 & 0.12 & 0.90 & 0.03 & 0.51 & 0.07 & 0.61 \\
\hline & S17 & 0.05 & 0.55 & 0.09 & 0.69 & 0.03 & 0.38 & 0.05 & 0.46 \\
\hline & S18 & 0.04 & 0.47 & 0.08 & 0.59 & 0.02 & 0.33 & 0.04 & 0.39 \\
\hline & S19 & 0.64 & 0.07 & 0.13 & 0.85 & 0.34 & 0.05 & 0.07 & 0.47 \\
\hline & S20 & 0.34 & 0.04 & 0.07 & 0.45 & 0.18 & 0.03 & 0.04 & 0.25 \\
\hline & $\mathrm{S} 21$ & 0.93 & 0.15 & 0.20 & 1.28 & 0.50 & 0.11 & 0.11 & 0.71 \\
\hline & Mean & 0.25 & 0.48 & 0.12 & 0.85 & 0.14 & 0.34 & 0.07 & 0.54 \\
\hline
\end{tabular}

the aboveground tissues of the under- mass of the understorey is inversely corre- Carbon storage in the litter and soil of storey $\left(C_{\text {st-Understorey-ABC }}\right)$. This shows that the lated to the cork oak stand density (with $\mathrm{R}^{2}$ the cork oak stands stock of carbon in the aboveground bio- $=0.69$ ).

The carbon concentrations in the litter

Tab. 5 - Carbon concentrations in the litter and the soil at different soil depths. (D): stand density of the cork oak stand (stem ha-1).

\begin{tabular}{|c|c|c|c|c|c|c|c|}
\hline \multirow[b]{2}{*}{$\begin{array}{l}\text { Density class } \\
\left(\text { stem ha }{ }^{-1}\right)\end{array}$} & \multirow[b]{2}{*}{ Stand } & \multirow[b]{2}{*}{$\begin{array}{l}\text { Litter } \\
\left(\mathrm{g} \mathrm{kg}^{-1}\right)\end{array}$} & \multicolumn{5}{|c|}{ Soil depth (cm) } \\
\hline & & & $\begin{array}{c}0-20 \\
\left(\mathrm{~g} \mathrm{~kg}^{-1}\right)\end{array}$ & $\begin{array}{l}20-40 \\
\left(\mathrm{~g} \mathrm{~kg}^{-1}\right)\end{array}$ & $\begin{array}{l}40-60 \\
\left(\mathrm{~g} \mathrm{~kg}^{-1}\right)\end{array}$ & $\begin{array}{c}60-80 \\
\left(\mathrm{~g} \mathrm{~kg}^{-1}\right)\end{array}$ & $\begin{array}{l}80-100 \\
\left(\mathrm{~g} \mathrm{~kg}^{-1}\right)\end{array}$ \\
\hline $\mathrm{D}=0$ & Open area & - & 3.0 & 0.6 & 0.1 & 0.1 & 0.1 \\
\hline \multirow[t]{7}{*}{$D<100$} & S1 & 550 & 9.7 & 0.7 & 1.0 & 0.1 & 0.1 \\
\hline & $\mathrm{S} 2$ & 560 & 12.0 & 2.5 & 0.9 & 0.1 & 0.1 \\
\hline & S3 & 550 & 14.3 & 2.9 & 0.6 & 0.1 & 0.1 \\
\hline & S4 & 540 & 10.8 & 1.1 & 1.0 & 0.1 & 0.1 \\
\hline & S5 & 550 & 11.0 & 2.2 & 0.8 & 0.1 & 0.1 \\
\hline & S6 & 550 & 12.0 & 0.8 & 0.6 & 0.1 & 0.1 \\
\hline & Mean & 550 & 11.6 & 1.7 & 0.8 & 0.1 & 0.1 \\
\hline \multirow[t]{6}{*}{$100 \leq D \leq 200$} & S7 & 550 & 12.5 & 3.4 & 0.9 & 0.1 & 0.1 \\
\hline & S8 & 540 & 11.3 & 2.1 & 0.6 & 0.1 & 0.1 \\
\hline & S9 & 550 & 12.1 & 3.2 & 0.7 & 0.1 & 0.1 \\
\hline & $\mathrm{S} 10$ & 550 & 15.3 & 1.9 & 1.1 & 0.1 & 0.1 \\
\hline & $\mathrm{S} 11$ & 550 & 14.8 & 2.3 & 1.8 & 0.1 & 0.1 \\
\hline & Mean & 550 & 13.4 & 2.5 & 1.1 & 0.1 & 0.1 \\
\hline \multirow[t]{10}{*}{$D>200$} & $\mathrm{~S} 13$ & 550 & 21.0 & 2.6 & 1.3 & 0.2 & 0.1 \\
\hline & S14 & 550 & 17.8 & 4.5 & 1.4 & 0.1 & 0.1 \\
\hline & $\mathrm{S} 15$ & 560 & 23.7 & 4.1 & 1.8 & 0.3 & 0.1 \\
\hline & $\mathrm{S} 16$ & 550 & 23.4 & 3.7 & 1.3 & 0.2 & 0.1 \\
\hline & $\mathrm{S} 17$ & 540 & 20.1 & 2.5 & 1.6 & 0.3 & 0.1 \\
\hline & $\mathrm{S} 18$ & 540 & 32.3 & 9.2 & 2.5 & 0.3 & 0.1 \\
\hline & $\mathrm{S} 19$ & 550 & 21.4 & 2.9 & 1.5 & 0.2 & 0.1 \\
\hline & $\mathrm{S} 20$ & 540 & 20.6 & 4.3 & 2.1 & 0.1 & 0.1 \\
\hline & S21 & 550 & 17.0 & 2.3 & 1.0 & 0.1 & 0.1 \\
\hline & Mean & 550 & 21.9 & 4.0 & 1.6 & 0.2 & 0.1 \\
\hline
\end{tabular}


and soils varied from 540 to $560 \mathrm{~g} \mathrm{~kg}^{-1}$ for the litter and between 0.1 to $32 \mathrm{~g} \mathrm{~kg}^{-1}$ for the soil (Tab. 5). The lowest organic carbon concentrations were observed at the deepest soil depth (i.e., $80-100 \mathrm{~cm}$ soil depth), although these low values of $0.1 \mathrm{~g} \mathrm{~kg}^{-1}$ were attained in some stands from $60 \mathrm{~cm}$ downwards and in the open area from $40 \mathrm{~cm}$ downwards (Tab. 5). The lowest carbon concentrations in the top soil layers (i.e., o$20 \mathrm{~cm}$ soil depth) were found in the stands with the lowest stand density (with values ranging between 9.7-14.3 $\mathrm{g} \mathrm{kg}^{-1}$ and a mean value of $11.6 \mathrm{~g} \mathrm{~kg}^{-1}$ ). Elsewhere, the carbon concentrations of this soil depth layer were intermediate $\left(18.5 \mathrm{~g} \mathrm{~kg}^{-1}\right)$. The values for the open area were very low, even in the top soil layer ( $3 \mathrm{~g} \mathrm{~kg}^{-1}$ or lower). The minimum and maximum organic carbon stocks at the stand scale ranged between 0.2-8.1 $\mathrm{Mg} \mathrm{ha}{ }^{-1}$ of carbon for the litter and 34.8118.2 Mg ha-1 for the soil $(0-100 \mathrm{~cm})$. Fig. 2 displays the average carbon stocks per ha for each stand density class. The total stocks of organic carbon in the soils of our study (total of $0-100 \mathrm{~cm}$ soil depths) varied on average from 12.5 to $81.2 \mathrm{Mg} \mathrm{ha}^{-1}$ for the open area and the highest stand density class, respectively (Fig. 2), with an overall average of $58 \mathrm{Mg} \mathrm{ha}^{-1}$. With the exception of stand S18 (118 Mg ha-1), the organic carbon stocks in the first $100 \mathrm{~cm}$ of the soil did not exceed $86 \mathrm{Mg} \mathrm{ha}^{-1}$. The relative importance of the different soil layers is given in Tab. 6. Soil depth appeared to be the most important factor explaining the observed differences. With the exception of stand $\mathrm{S} 18$, the carbon stocks within the first 40

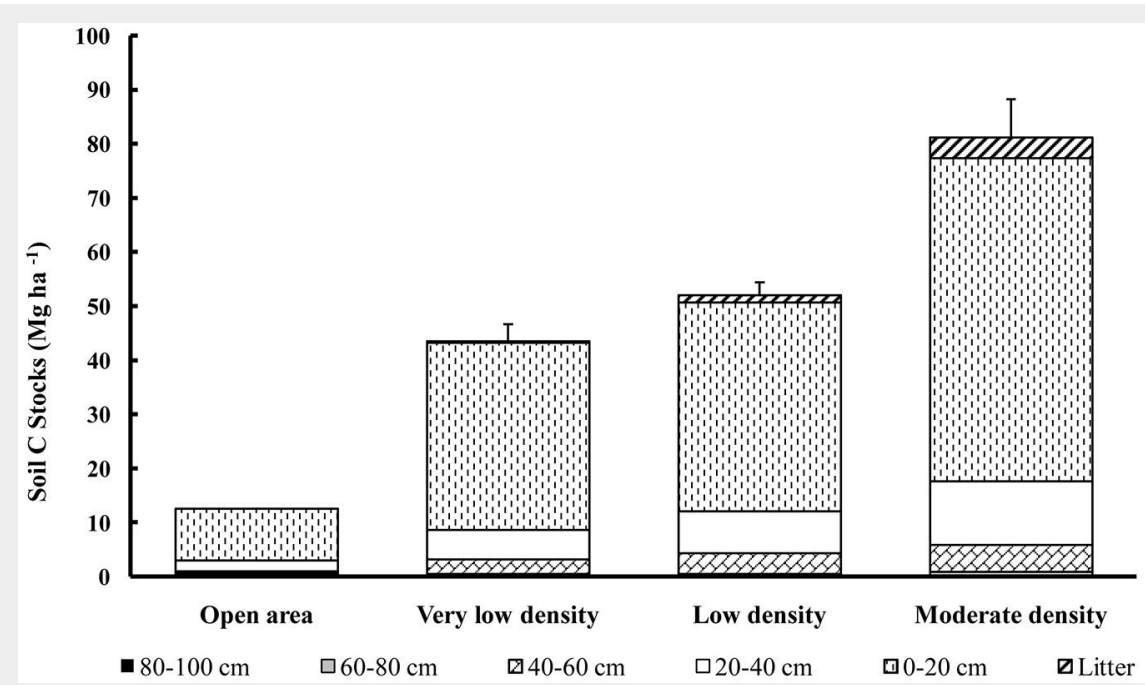

Fig. 2 - Mean organic carbon stocks $\left(\mathrm{Mg} \mathrm{ha}^{-1}\right)$ in the litter and in the first $100 \mathrm{~cm}$ of the soil. Error bars represent the standard error.
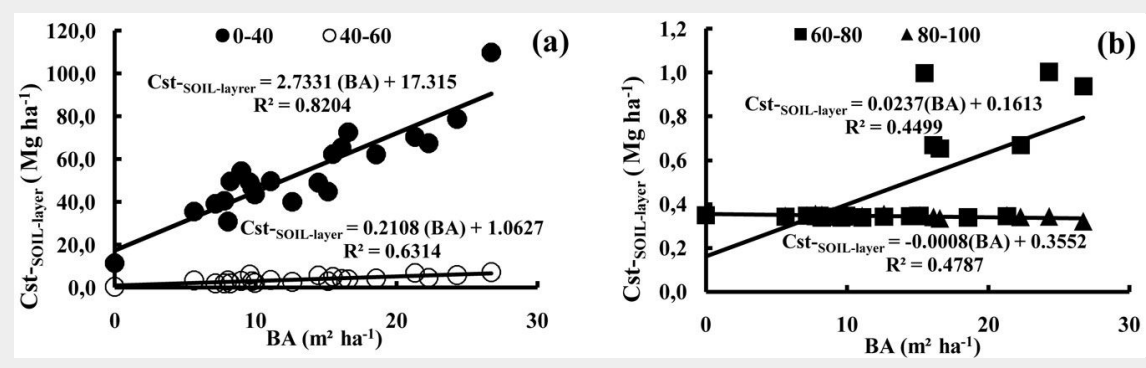

Fig. 3 - Relationships between basal area $\left(B A, m^{2}\right.$ ha $\left.{ }^{-1}\right)$ and stocks of organic carbon in the soil layers $\left(C_{\text {st-solt-layer }}, \mathrm{Mg}\right.$ ha $\left.{ }^{-1}\right) ;(\mathrm{BA})$ : basal area $\left(\mathrm{m}^{2} \mathrm{ha}^{-1}\right)$.

Tab. 6 - Relative contribution to the total soil organic carbon pool of the five soil layers studied.

\begin{tabular}{|c|c|c|c|c|c|c|}
\hline \multirow{2}{*}{$\begin{array}{l}\text { Density class } \\
(\text { stem ha-1) }\end{array}$} & \multirow[b]{2}{*}{ Stand } & \multicolumn{5}{|c|}{ Relative contribution per soil depth $(\mathrm{cm})$} \\
\hline & & $\begin{array}{l}0-20 \\
(\%)\end{array}$ & $\begin{array}{c}20-40 \\
(\%)\end{array}$ & $\begin{array}{c}40-60 \\
(\%)\end{array}$ & $\begin{array}{c}60-80 \\
(\%)\end{array}$ & $\begin{array}{c}80-100 \\
(\%)\end{array}$ \\
\hline $\mathrm{D}=0$ & Open area & 75.8 & 15.8 & 2.7 & 2.8 & 2.8 \\
\hline \multirow[t]{7}{*}{$D<100$} & S1 & 81.9 & 6.6 & 9.5 & 1.0 & 1.0 \\
\hline & S2 & 75.6 & 16.7 & 6.3 & 0.7 & 0.7 \\
\hline & S3 & 77.7 & 17.2 & 3.7 & 0.6 & 0.7 \\
\hline & S4 & 80.8 & 9.0 & 8.5 & 0.9 & 0.9 \\
\hline & S5 & 75.9 & 16.3 & 6.2 & 0.8 & 0.8 \\
\hline & S6 & 87.1 & 6.4 & 4.8 & 0.8 & 0.8 \\
\hline & Mean & 79.8 & 12.0 & 6.5 & 0.8 & 0.8 \\
\hline \multirow[t]{7}{*}{$100 \leq D \leq 200$} & S7 & 71.6 & 21.1 & 5.9 & 0.7 & 0.7 \\
\hline & S8 & 77.9 & 15.8 & 4.7 & 0.8 & 0.8 \\
\hline & S9 & 72.6 & 21.1 & 4.8 & 0.7 & 0.7 \\
\hline & S10 & 81.0 & 11.0 & 6.7 & 0.6 & 0.6 \\
\hline & S11 & 75.3 & 12.6 & 10.9 & 0.6 & 0.6 \\
\hline & $\mathrm{S} 12$ & 76.3 & 12.0 & 10.4 & 0.6 & 0.6 \\
\hline & Mean & 75.8 & 15.6 & 7.2 & 0.7 & 0.7 \\
\hline \multirow[t]{10}{*}{$D>200$} & S13 & 81.8 & 11.1 & 5.7 & 0.9 & 0.5 \\
\hline & S14 & 73.2 & 19.4 & 6.3 & 0.5 & 0.5 \\
\hline & S15 & 77.7 & 13.9 & 6.8 & 1.2 & 0.4 \\
\hline & S16 & 79.8 & 13.9 & 5.1 & 0.8 & 0.4 \\
\hline & S17 & 79.6 & 11.1 & 7.4 & 1.4 & 0.5 \\
\hline & $\mathrm{S} 18$ & 71.0 & 21.8 & 6.1 & 0.8 & 0.3 \\
\hline & S19 & 80.9 & 11.4 & 6.3 & 0.9 & 0.5 \\
\hline & S20 & 73.5 & 16.8 & 8.8 & 0.4 & 0.4 \\
\hline & $\mathrm{S} 21$ & 81.3 & 12.1 & 5.4 & 0.6 & 0.6 \\
\hline & Mean & 77.6 & 14.6 & 6.4 & 0.8 & 0.5 \\
\hline
\end{tabular}




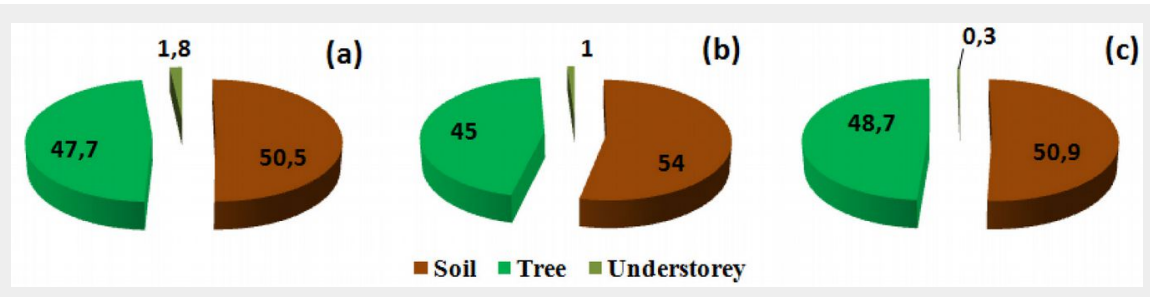

Fig. 4 - Contribution of the three components of the ecosystem (tree, understorey and soil) to total carbon stocks. (a): lowest stand density class ( $D<100$ stems ha $\left.{ }^{-1}\right)$; (b): moderate density class $\left(100<\mathrm{D}<200\right.$ stems ha $\left.^{-1}\right)$; (c) highest density class ( $>200$ stems $\left.\mathrm{ha}^{-1}\right)$.

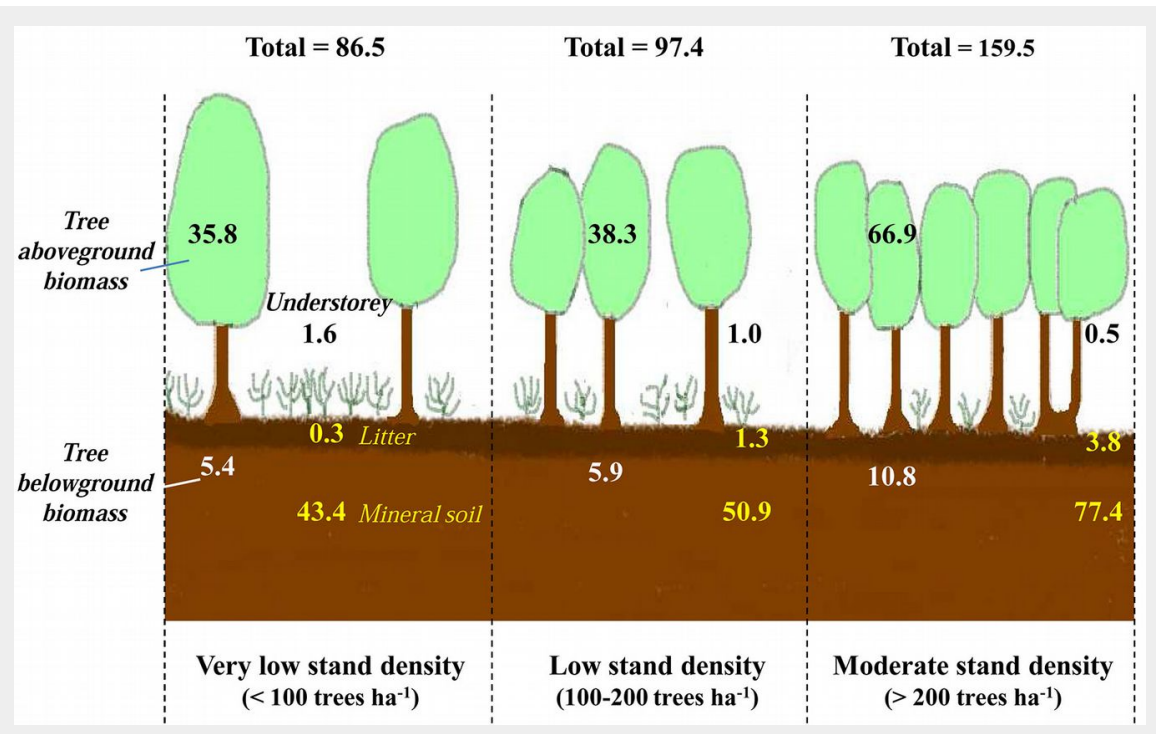

Fig. 5 - Change in the average carbon stocks $\left(\mathrm{Mg} \mathrm{ha}^{-1}\right)$ in different compartments, depending on the cork oak stand density.

$\mathrm{cm}$ of the soil profile did not exceed $78 \mathrm{Mg}$ ha ${ }^{-1}$. In all stands, more than $72 \%$ of the total carbon stocks were present within the first $20 \mathrm{~cm}$ of the soil. Then, for the first 40 $\mathrm{cm}$ of soil, this value was over $88 \%$ of the total carbon stocks in the soil (Tab. 6). For the investigated stands, the total organic carbon stocks (in $0-40 \mathrm{~cm}$ and in $40-60 \mathrm{~cm}$ soil depths) were dependent on the total basal area of the stands (Fig. 3a). In contrast, the carbon stocks of the $60-80$ and 80-100 cm soil depths did not show any significant relationship with basal area (Fig. 3b).

\section{Discussion and conclusions}

\section{General considerations}

When evaluating ecosystem stocks and fluxes, the computed values probably include both spatial and temporal variations (Yanai et al. 2012). Temporal variation such as differences in the ecology between seasons or between years for some fluctuating parameters - seems of minor importance in our study, relative to the biomass of the cork oak stands. In the longer term, events such as cuttings or annual growth will of course change the biomass of our stands slightly, but the data of the present study are robust for the year of our inventory. The sampling effort in the present study included the complete inventory of 21 stands (central parts of 1 ha each) in the western part of Mamora forest, having a total surface area of around 25000 ha, where cork oak is still present. The inventory consisted of all trees present in these plots, and the structure (diameter distribution) was representative of the forest area in these cantons. The equation used for assessing the tree volume gave very comparable results to the outcome reported by Makhloufi et al. (2008) in the mountainous regions of Morocco, even though we had to restrict the entry to our model to only one parameter, i.e., the circumference at breast height. The equations used to estimate either aboveground or belowground tissues of the cork oak included several equations obtained from the literature (Ruiz-Peinado et al. 2012), but these were from a similar context, were based on a similar diameter range and the values for stem and trunk biomass in both their and our equations were similar. However, as most stems in our study forest were growing from stools, it is not impossible that the equation used might lead to some underestimation of total root biomass (Vade- boncoeur et al. 2007). Overall, given that 21 stands of 1 ha were sampled in the area, we are confident that the biomass values obtained for these stands are valid in the experimental context of the Mamora forest, and that the estimates do not suffer from a strong spatial variation.

As stated by Augusto et al. (2009), rather than choosing allometric relationships from the literature or established for the study, there is a need to ensure that nutrient concentration values obtained locally are used, due to the higher uncertainty when using those from literature. Accordingly, we used locally-obtained carbon concentrations to compute our carbon stocks. Overall, the sampling effort and prediction for the cork oak volume, biomass and carbon content seem adequate and the obtained data for biomass and carbon storages were in line with those from the literature (see below). The understorey was inventoried on a complete basis (extensively in all the 21 stands) for the aboveground biomass, and 10 individuals per species were harvested to establish speciesspecific root/shoot ratios. Likewise, carbon concentrations were assessed for all of the plant species-compartment combinations. As a consequence, the sampling effort seems appropriate for this compartment of the ecosystem in our 21 stands. Outside our stands, variation in the understorey may be somewhat larger; in particular, some more species can be expected, such as the Mamora pear or the mastic tree.

Soils and litter were sampled with a twostep sampling strategy, with 1 sample every $100 \mathrm{~m}^{2}$ subplot before generating the composite samples used for analysis, yielding 25 individual samples and one composite sample per layer. This should overcome problems of spatial variability (Yanai et al. 2012), and seems an adequate sampling intensity for our conditions (Yanai et al. 2003). However, some temporal variability must occur, notably for the litter samples, as this layer is the most exposed to microclimatic effects (including fast oxidation of organic matter - Lepoutre 1967). Overall, we feel confident in the values produced for the carbon stocks in the ecosystem of our experimental context.

\section{Carbon in trees and understorey vegetation}

In our study the values of aboveground biomass per tree ranged from 26 to $2177 \mathrm{~kg}$ (mean value of $379 \mathrm{~kg}$ ). Such range fairly overlaps those reported by Makhloufi et al. (2008) for Morocco (range: 11-1255) and by Ruiz-Peinado et al. (2012) for Spain (range: 11-2412 kg). In this study, the 38.1-170.2 Mg $\mathrm{ha}^{-1}$ for the aboveground biomass of cork oak stands is fairly comparable to the mean biomass of 34 and $183 \mathrm{Mg} \mathrm{ha}^{-1}$ for Quercus ilex stands respectively in the high and middle Atlas in Morocco (Boulmane 2010). The respective carbon stocks in the aboveground parts of the cork oak vary from 21.3 to $94.8 \mathrm{Mg} \mathrm{ha}{ }^{-1}$. To our knowledge, this is 
the first work reporting carbon stocks in cork oak forests. Indeed, Quercus species, such as Q. canariensis, Q. faginea and Q. suber have been poorly studied so far, des pite their great ecological and economic importance (Ruiz-Peinado et al. 2012). The observed range compares well with species of the same genus, such as Quercus ilex (17-91 Mg ha-1 of carbon - Boulmane et al. 2010), though these figures are much lower than those reported for mature stands of exotic fast growing species such as Pinus pinaster Ait. in the same region (166-249 Mg ha-1 of carbon - Ruiz-Peinado et al. 2013).

Root biomass was reported to account for $10-40 \%$ of total tree biomass (MacDicken 1997), between one fifth and one third for coniferous species (Ruiz-Peinado et al. 2011) and between $15-49 \%$ for deciduous species (Ruiz-Peinado et al. 2012). Commonly, root biomass is supposed to be scaled to the aboveground dimensions rather than tree age or the growing site (Drexhage \& Colin 2001, Le Goff \& Ottorini 2001), although trees growing in dense or open stands were shown to have different root/shoot ratios (Ritson \& Sochacki 2003). Root biomass values in our study ranged between 5.9-28.2 Mg ha', representing about $14 \%$ of the total tree biomass, thus close to the lower values reported for deciduous species (10-49\% - MacDicken 1997, Ruiz-Peinado et al. 2012). Regarding the carbon content in trees, roots were reported to make up between $13-15 \%$ of the carbon content of trees, though most studies state that the estimate for the belowground part is rather inprecise (Lossaint \& Rapp 1971, Arrouays et al. 1999, Dupouey et al. 1999, Rapp et al. 1999, Montes et al. 2002, Pansu 2006). Indeed, despite the large size of root biomass as a carbon pool, roots remain relatively poorly studied, as the methods for their assessment is always complex and very time consuming (Rondeux 1993, MacDicken 1997, Millikin et al. 1997). Concerning the soil, roots were also credited as being a large carbon pool ( $\mathrm{Na}$ delhoffer \& Raich 1992), representing between 20 to $40 \%$ of the total carbon stocks in forest soils (Jackson et al. 1997). Here, the amount of carbon stored in the roots of cork oak varied between 3.2-15.2 $\mathrm{Mg}$ ha $^{-1}$ for the lowest and highest stands, respectively. Such content is rather low compared with the recorded values for tropical and temperate forests (21-22 $\mathrm{Mg} \mathrm{ha}^{-1}$ - Jackson et al. 1997) or even boreal forests (14 Mg ha-1 - Jackson et al. 1997).

The understorey was reported to represent between $1-7 \%$ on average of the total ecosystem aboveground biomass for temperate forests (Dupouey et al. 2000, Peichl \& Arain 2006, Gonzalez et al. 2013). Under high light conditions due to low stand density or more canopy openings, understorey biomass would be expected to be higher (Sabo et al. 2009, Ares et al. 2010), as more light and more resources such as water and nutrients are available for understorey primary productivity (Gonzalez et al. 2013). For our cork oak stands, despite a low stand density and the presence of openings throughout the stands, the part of understorey vegetation in the total aboveground ecosystem biomass varied on average between only 0.4 to $2.3 \%$ of total stand aboveground biomass for stand densities over 200 stems ha $^{-1}$ and below 100 stems $h a^{-1}$, respectively. This rather low value probably reflects the low fertility and the overexploitation in this area for decades, if not centuries. In addition, part of the understorey has probably been harvested for fuel wood or charcoal production. The total carbon storage was only $0.3-2.9 \mathrm{Mg}$ $\mathrm{ha}^{-1}$, with an average of $1.0 \mathrm{Mg} \mathrm{ha} \mathrm{M}^{-1}$. These values are lower than those obtained for Pinus pinaster stands in the south west of France, with mean carbon stocks for the understorey of $1.7 \mathrm{Mg} \mathrm{ha}^{-1}$ and a range of 0.7-4.1 Mg ha ${ }^{-1}$ (Porté et al. 2009). Under our conditions, the aboveground carbon stocks in the understorey decrease with increasing cork oak stand density, which can be explained by the competition for light between trees and the understorey.

\section{Carbon storage in the litter and soil of the cork oak stands}

The litter of the western area of the Mamora forest contained between 0.2 and $8.1 \mathrm{Mg} \mathrm{ha}^{-1}$ of organic carbon. These values are close to the 3.5-8.6 Mg ha-1 reported for Quercus ilex stands in Morocco (Boulmane et al. 2010). In comparison, the arenosols of European forests show higher carbon stocks in the litter layer (Dupouey et al. 1999, Baritz et al. 2010), except under a Mediterranean climate where this pool is similar in size (Baritz et al. 2010). The rather low values for the Mamora forest can be explained by the human pressure on the area, including pasture with cattle and collection of dead woody debris (branches, twigs) as fire wood by the local population. Carbon concentration generally decreases with increasing depth of the mineral soil (Augusto et al. 2010, Diaz-Pinés et al. 2011). This general pattern was also observed in all our stands. Furthermore, the lowest values for the topsoil were observed in the stands with the lowest stand density. As a result, both soil depth and stand density explained differences in organic carbon stocks in our stands. With the exception of 1 out of the 21 stands investigated, the carbon stocks in the top $40 \mathrm{~cm}$ did not exceed $78 \mathrm{Mg} \mathrm{ha}^{-1}$. Therefore, our values were close to those (40-70 $\mathrm{Mg} \mathrm{ha}^{-1}$ ) observed by Diaz-Pinés et al. (2011) in $50 \mathrm{~cm}$ of soil underneath a Quercus pyrenaica Willd. stand in the center of Spain, but inferior to the $100 \mathrm{Mg} \mathrm{ha}^{-1}$ reported by Sabir \& Roose (2002) for a $30 \mathrm{~cm}$ deep soil profile in a weakly degraded cork oak forest in the Rif mountains in Morocco. In our study, a strong decrease of carbon content with depth occurred in all stands. This result is consistent with the scientific literature, as topsoil is shown to contain the major part of the soil organic carbon pool in Mediterranean forest ecosystems (Augusto et al. 2010, Boulmane et al. 2008, 2010, 2014, Chiti et al. 2012, Pulido-Fernández et al. 2013). The relative contribution of topsoil to the soil pool of organic carbon of our degraded Mediterranean forest (here as much as $88 \%$ of all the organic carbon was contained in the top $40 \mathrm{~cm}$ ) was notably higher than values commonly reported for the first $100 \mathrm{~cm}$ of soils throughout the world (Batjes 1996). Presumably, some further carbon is present below the first 100 $\mathrm{cm}$ of soil, but concentrations were at least 100 times lower than in the top soil, so that likely this share of carbon overlooked in our calculations is overall very low.

The total stocks of organic carbon in the soils of our study (total of $0-100 \mathrm{~cm}$ soil depths) ranged from 35 to $118 \mathrm{Mg} \mathrm{ha}^{-1}$, with an overall average of $58 \mathrm{Mg} \mathrm{ha}^{-1}$. The entire forest of Mamora has been disturbed by human and animal pressure, sparing no stand density class. Therefore, the total organic carbon stocks for the top $60 \mathrm{~cm}$ were correlated to the total stand basal area, underlining the relationship between the soil and the trees (notably by inputs of organic carbon by aboveground- and belowground litter, which protect against erosion and leaching). The open areas have even lower organic carbon stocks, as no new organic matter inputs from trees to soil occur, and existing organic matter degrades rapidly. The average value of $58 \mathrm{Mg}$ $\mathrm{ha}^{-1}$ for organic carbon stocks in the first $100 \mathrm{~cm}$ of the soil is clearly lower than the 136 and $152 \mathrm{Mg}^{-1}$ given by Eglin (2005) and Lecointe et al. (2005), respectively. Soils from the Mediterranean region are relatively poor in carbon (Rodríguez-Murillo 2001) and studies on carbon stocks in soils have shown that the organic carbon stocks may vary considerably with the soil type (Batjes 1996, Droogers \& Bouma 1997, Bouma et al. 1998, Baritz et al. 2010). For a soil depth of $100 \mathrm{~cm}$, values range from 12 $\mathrm{Mg}$ ha $^{-1}$ for Xerosols to more than $100 \mathrm{Mg}$ ha ${ }^{-1}$ for Podzols.

\section{Total carbon storage of the cork oak ecosystems}

The soil is a key reservoir for carbon and may contain up to two-thirds of the total ecosystem carbon stocks (Dixon et al. 1994, Mao et al. 2010). This has also been demonstrated in Mediterranean forest ecosystems (Ruiz-Peinado et al. 2013 and references therein). In our context, for the three stand density classes considered, the first $100 \mathrm{~cm}$ of the soil (including the forest floor) represented the major storage compartment of this ecosystem, with roughly $51 \%$ of the total organic carbon stocks (Fig. 4). The biomass of the cork oak, including aboveground and belowground tissues, constituted the second largest pool of carbon (more than $47 \%$ ) and the contribution of the understorey to the total organic carbon stocks was less than $2 \%$ (Fig. 4).

In holm oak (Quercus ilex) ecosystems 
from the middle Atlas Mountains in Morocco the stock of organic carbon in litter and soils represents between 40 and $55 \%$ of the total organic carbon stocks (Boulmane 2010, Boulmane et al. 2014). Such distribution over pools depends apparently on the biome. Indeed, tropical forests were reported to have $56 \%$ of carbon stored in biomass and $32 \%$ in soil, whereas boreal forests had only $20 \%$ in biomass and $60 \%$ in soil, the remaining carbon being withheld in dead wood and litter (Pan et al. 2011).

According to the FAO (2006), carbon stocks in forests in North Africa (the total carbon in biomass, dead wood, forest floor and the first $30 \mathrm{~cm}$ of the soil profile) were on average $64.9 \mathrm{Mg} \mathrm{ha}^{-1}$. Here, the total stock of organic carbon in the first $20 \mathrm{~cm}$ of soil ranged from 58 to $202 \mathrm{Mg} \mathrm{ha}^{-1}$, with an average stock of $107 \mathrm{Mg} \mathrm{ha}^{-1}$, which is somewhat higher than the overall FAO estimate.

Based on our results, the deforestation of 1 hectare of cork oak would lead to a loss of $183 \mathrm{Mg} \mathrm{ha} \mathrm{H}^{-1}$ of $\mathrm{CO}_{2}$. Such deforestation would eventually induce a loss of organic carbon from the soil organic carbon stocks of more than $79 \%$, underlining the strong relationship between stand biomass and soil carbon. The extremely dry soil conditions may actually exacerbate this loss of organic soil carbon (Lepoutre 1967), as organic material can be oxidized rapidly whenever soils are bare or lose their cover. Boulmane (2010) showed that this loss could even be as high as $90 \%$. This confirms that forest is the land use having the highest stock of soil carbon, thereby human activities that modify these ecosystems can profoundly affect both carbon reservoirs in biomass but also in soils (Rodríguez-Murillo 2001). The stock of organic carbon within all of the compartments studied (tree biomass, understorey biomass, forest floor and the first $100 \mathrm{~cm}$ of soil) are very well correlated with the density of the cork oak stands. In particular, with the exception of the understorey vegetation, the higher the stand density, the higher the carbon stocks in these stands (Fig. 5). This tight link may be the result of the high dependency of soil carbon stocks on litterfall fluxes, provided that the litter on soil remains undisturbed, as suggested by the location of almost all of the soil carbon pool in the upper-most layer of soil profiles. According to Fischlin et al. (2007) in the context of climate change, Mediterranean forests are considered vulnerable with a risk of biodiversity loss and a decreased function of carbon sequestration. As a consequence, a sustainable forest management scheme should be applied in line with multi-criterion objectives aimed at optimizing both the increase of biomas and the sequestration of carbon (Bravo et al. 2008).

In this context and taking into consideration the results of this study with the objec tive of improving the carbon storage capacity in this ecosystem, there is a need to encourage management strategies that favor the restoration of cork oak stands. To this end, we propose:

- to temporarily prevent the access to lowdensity stands (less than 200 stems ha-1) with fences, followed by seeding or plantations of cork oak seedlings from local nurseries, with the aim of increasing the stand density up to more that 200 stems ha ${ }^{-1}$;

- to fence the open areas within the stands which have resulted from the degradation of the cork oak forest, where Quercus suber plantations should be established, with the aim of locally restoring the canopy cover by this species.

- to promote among local users and stakeholders the awareness of the numerous functions of such forest (notably ecological) and of the negative impact of its irrational exploitation.

\section{Conclusions}

Regarding our first objective, the present study showed that the total organic carbon stocks in the cork oak forests investigated range from 65 to $237 \mathrm{Mg} \mathrm{ha}^{-1}$, with an average total organic carbon stock of $121 \mathrm{Mg}$ $\mathrm{ha}^{-1}$. These stocks, which are relatively low, can be explained by the widespread degradation and the high pressure the Mamora forest is subjected to. The soil is the major reservoir of carbon in such ecosystem: more than $88 \%$ of the organic carbon was found within the first $40 \mathrm{~cm}$ of the soil profile. Carbon stocks estimates varied considerably with the basal area of the cork oak stands. The biomass of cork oak trees represents the second largest carbon pool, whereas the understorey biomass poorly contributes (less than $2 \%$ ) to the total organic carbon stocks. Concerning our second objective, the main parameter correlated with carbon stocks in this cork oak forests was the tree density of stands. Indeed, the stand density was strongly related to the total carbon sequestration within the three main compartments: tree biomass, soil and understorey vegetation. As such, a shift from dense to open cork oak stands due to overexploitation implies a calculated loss in total organic carbon stocks of around $47 \%$ on average. Loss of carbon in tree biomass and in the first $100 \mathrm{~cm}$ of soil in low-density cork oak stands is not compensated by an increase of carbon in the understorey vegetation (representing less than $2 \%$ of the total carbon pool). Regarding our third objective, forest managers should implement silvicultural practices aimed at increasing the stand density and enhancing the public awareness among forest users to avoid continued over-exploitation.

\section{Acknowledgements}

The authors express their gratitude to the technicians Ms Bounimi Zhour, M Amrani and M Aaziz at the Centre de Recherche Forestière in Rabat (Morocco), for their valuable contributions in the field and in the chemical analysis of samples. We also acknowledge the bilateral project between France and Morocco PRAD 01/13 "Projet de Recherche Agronomique pour Developpement" for the financial support, permitting the exchange of staff and constructive work sessions.

\section{References}

Aafi A, Achhal EL Kadmiri A, Benabid A, Rouchdi M (2005a). Richesse et diversité floristique de la subéraie de la Mamora (Maroc) [Floristic richness and diversity of the cork oak forest of Mamora (Morocco)]. Acta Botanica Malacitana 30: 127-138. [in French] [online] URL: http:// www.bioveg.uma.es/abm/volumenes/vol30/08. mamora.pdf

Aafi A, Achhal EL Kadmiri A, Benabid A, Rouchdi $M$ (2005b). Utilisation des images satellitaires SPOT pour la cartographie des types de peuplements de la forêt de la Mamora (Maroc) [Using SPOT satellite images for mapping types of stands in the forest of Mamora (Morocco)]. Revue Française de Photogrammétrie et Télédétection 178 (2): 30-35. [in French]

Aafi A (2007). Etude de la diversité floristique de l'écosystème de Chêne-liège de la forêt de la Maamora [Study of the floral diversity of the ecosystem of Cork oak forest of Maamora]. Thèse de Doctorat D'Etat Es-Sc Agronomiques, Institut Agronomique et Vétérinaire Hassan II, Rabat, Maroc, pp. 190. [in French] [online] URL: http://www.agrimaroc.org/index.php/Actes_IA $\mathrm{VH} 2 /$ thesis/view/30

Aafi A, Benabid A, El Kadmiri Achhal A (2008). Caractérisation de la subéraie de la Mamora: flore, phytocénose, structure-architecture et cartographie [Characterization of the cork oak forest of Mamora: flora, plant community structure, architecture and mapping]. Annales de la Recherche Forestière au Maroc 39: 21-35. [in French] [online] URL: http://cat.inist.fr/? aModele $=$ affi cheN\&cpsidt $=21771330$

Anne P (1945). Sur le dosage rapide du carbone organique des sols [The rapid assay of soil organic carbon]. Annales Agronomiques 2: 161172. [in French]

Ares A, Neill AR, Puettmann KJ (2010). Understory abundance, species diversity and functional attribute response to thinning in coniferous stands. Forest Ecology and Management 260: 1104-1113. - doi: 10.1016/j.foreco.2010.06.0 23

Arrouays D, Deslais W, Daroussin J, Balesdent J, Dupouey JL, Nys C, Badeau V, Belkacem S (1999). Stocks de carbone dans les sols de France: quelles estimations? [Carbon stocks in soils of France: which estimates?] CRAAF, Vol 85, N 6, Edition Académie des Sciences Française, Paris, France, pp. 278-292. [in French] Augusto L, Bakker MR, De Lavaissiere C, Jordan Meille L, Saur E (2009). Estimation of nutrient content of woody plants using allometric relationships: quantifying the difference between concentration values from the literature and actuals. Forestry 82: 463-477. - doi: 10.1093/fore stry/cppo19

Augusto L, Bakker MR, Morel C, Meredieu C, Trichet P, Badeau V, Arrouays D, Plassard C, Achat DL, Gallet-Budynek A, Merzeau D, Canteloup D, Najar M, Ranger J (2010). Is "grey literature" a reliable source of data to characte- 
rize soils at the scale of a region? A case study in a maritime pine forest in southwestern France. European Journal of Soil Science 61: 807-822. - doi: 10.1111/j.1365-2389.2010.01286.x Baritz R, Seufert G, Montanarella L, Van Ranst E (2010). Carbon concentrations and stocks in forest soils of Europe. Forest Ecology and Management 260: 262-277. - doi: 10.1016/j.foreco. 2010.03.025

Batjes NH (1996). Total carbon and nitrogen in the soils of the world. European Journal of Soil Science 47: 151-163. - doi: 10.1111/j.1365-2389.19 96.tbo1386.x

Belkacem S, Nys C, Dupouey JL (1998). Evaluation des stocks de carbone dans les sols forestiers: importance de la sylviculture et du milieu sur la variabilité [Assessment of carbon stocks in forest soils: the importance of forestry and environment on the variability]. INRA/DPE, Agriges, Ministère del l'environnement no. 6, 95/329/Poooo6, Paris, France, pp. 68. [in French]

Benabid A (2000). Flore et écosystèmes du Maroc: evaluation et préservation de la biodiversité [Morocco's flora and ecosystems assessment and conservation of biodiversity]. Ibis Press, Paris, France, pp. 359. [in French]

Benabid A, Fennane M (1994). Connaissances sur la végétation du Maroc: phytogéographie, phytosociologie et séries de végétation [Knowledge of Morocco's vegetation phytogeography, phytosociology and vegetation series]. Lazaroa 14: 21-97. [in French] [online] URL: http:// revistas.ucm.es/index.php/LAZA/article/view/LA ZA9494120021A

Bernoux M, Chevallier T, Cornet A (2013). Le carbone dans les sols des zones sèches. Des fonctions multiples indispensables [Carbon in dryland soils. Required multiple functions]. Les dossiers thématiques du Comité Scientifique Français de la Désertification no. 10, CSFD/ Agropolis International, Montpellier, France, pp. 40. [in French] [online] URL: http://www. documentation.ird.fr/hor/fdi:010061688

Boudy P (1952). Guide du forestier en Afrique du Nord [Forester's guide for North Africa]. La Maison Rustique, Paris, France, pp. 505. [in French]

Boulmane M, Halim M, El Antry-Tazi S, Berred K, El Harchaoui H (2008). Evaluation du stock du carbone et dynamique de la décomposition de la matière organique dans les sols de la Ma'mora [Rating carbon stock and dynamics of decomposition of organic matter in the soils of Ma'mora]. Annales de la Recherche Forestière au Maroc 39: 185-194. [in French][online] URL: http://cat.inist.fr/?aModele=afficheN\&cpsidt $=21$ 771346

Boulmane M (2010). Estimation du stock du carbone et des éléments nutritifs dans les Quercus rotundifolia du moyen atlas marocain et étude de la dynamique de décomposition de sa litière [Estimation of carbon stock and nutrients in Quercus rotundifolia of the middle Moroccan Atlas and study of the dynamics of the litter decomposition]. Ph.D. thesis, Département de Chimie, Université Mohammed V-Agdal Rabat, Maroc, pp. 211. [in French] [online] URL: http:// toubkal.imist.ma/handle/123456789/9329

Boulmane M, Makhloufi M, Bouillet JP, SaintAndré L, Satrani B, Halim M, El Antry S (2010).
Estimation du stock de carbone organique dans les Quercus ilex du Moyen Atlas Marocain [Estimated organic carbon stock in the Quercus ilex Moroccan Middle Atlas]. Acta Botanica Gallica 157: 451-467. [in French] - doi: 10.1080/125380 78.2010.10516222

Boulmane M, Santa Regina I, Khia AR, Oubrahim $H$ (2014). Estimation du stock de carbone organique dans les iliçaies du Moyen Atlas marocain [Estimated organic carbon stock in holm oak forests of the Middle Moroccan Atlas]. Nature and Technologie 11: 6-16. [in French] Bouma J, Batjes NH, Groot JJR (1998). Exploring land quality effects on world food supply. Geoderma 86: 43-59. - doi: 10.1016/So016-7061(98)o 0034-2

Bravo F, Bravo-Oviedo A, Diaz-Balteiro L (2008). Carbon sequestration in Spanish Mediterranean forests under two management alternatives: a modeling approach. European Journal of Forest Research 127: 225-234. - doi: 10.1007/ s10342-007-0198-y

Cerri CEP, Easter M, Paustian K, Killian K, Coleman K, Bernoux M, Falloon P, Powlson DS, Batjes N, Milne E, Cerri CC (2007). Simulating SOC changes in 11 land use change chronosequences from the Brazilian Amazon with Roth- $C$ and Century models. Agriculture Ecosystems and Environment 1: 1-12. - doi: 10.1016/j.agee.2007. 01.007

Chiti T, Diaz-Pinès E, Rubio A (2012). Soil organic carbon stock of conifers, broadleaf and evergreen broadleaf forests of Spain. Biology and Fertility of Soils 48 (17): 817-826. - doi: $10.1007 /$ s00374-012-0676-3

Davi H, Dufrêne E, Granier A, Le Dantec V, Barbaroux C, François C, Bréda C (2005). Modelling carbon and water cycles in a beech forest. Part II: Validation of the main processes from organ to stand scale. Ecological Modelling 1: 1-19. doi: 10.1016/j.agee.2007.01.007

De Graaff MA, Van Groenigen KJ, Six J, Hungate $B$, Van Kessel C (2006). Interactions between plant growth and soil nutrient cycling under elevated $\mathrm{CO}_{2}$ : a meta-analysis. Global Change Biology 12: 2077-2091. - doi: 10.1111/j.1365-2486. 2006.01240.x

De Sousa E, El Antry S, Atay Kadiri Z, Abourouh $M$ (2008). Problématique des subéraies dans le bassin méditerranéen [Problem of cork forests in the Mediterranean Basin]. Annales de la Recherche Forestière au Maroc 39: 63-73. [in French] [online] URL: http://cat.inist.fr/?aMode le=afficheN\&cpsidt $=21771334$

Diaz-Pinés E, Rubio A, Van Miegroet H, Montes F, Benito M (2011). Does tree species composition control soil organic carbon pool in Mediterranean mountain forests? Forest Ecology and Management 262: 1895-1904. - doi: 10.1016/j.for eco.2011.02.004

Dijkstra F, Cheng W (2008). Increased soil moisture content increases plant $\mathrm{N}$ uptake and the abundance of delta ${ }^{15} \mathrm{~N}$ in plant biomass. Plant and Soil 302 (1-2): 263-271. - doi: 10.1007/s11104007-9477-0

Dixon RK, Brown S, Houghton RA, Solomon AM, Trexler MC, Wisniewski J (1994). Carbon pools and fluxes of global forest ecosystems. Science 263 (5144): 185-190. - doi: 10.1126/science.263. 5144.185

Drexhage M, Colin F (2001). Estimating root sys- tem biomass from breast-height diameters. Forestry 74 (5): 491-497. - doi: 10.1093/forestry/ 74.5 .491

Droogers P, Bouma J (1997). Soil survey input in exploratory modelling of sustainable management practice. Soil Science Society of America Journal 61: 1704-1710. - doi: 10.2136/sssaj1997. 03615995006100060023x

Ducroux R, Baptiste JP, Ciais P, Orr J (2001). Limitation de l'effet de serre: synthèse des méthodes de captures et de stockages naturelles et artificielles du $\mathrm{CO}_{2}$ [Limiting the greenhouse effect: synthesis of methods for catching and natural and artificial storage of $\mathrm{CO}_{2}$ ]. Rapport ADEME-00-94-013, ADEME, Angers, France, pp. 51. [in French]

Dupouey JL, Pignard G, Badeau V, Thimonier A, Dhôte JF, Nepveu G, Bergès L, Augusto L, Belkacem S, Nys C (1999). Stocks et flux de carbone dans les forêts françaises [Carbon stock and fluxes in French forests]. CRAAF, Edition Académie des Sciences Française, Paris, France, vol. 85, no. 6, pp. 278-292. [in French]

Dupouey JL, Pignard G, Badeau V, Thimonier A, Dhôte J-F, Nepveu G, Berges L, Augusto L, Belkacem S, Nys C (2000). Stocks et flux de carbone dans les forêts françaises [Carbon stock and fluxes in French forests]. CRAAF, Edition Académie des Sciences Française, Paris, France, vol. 85, no. 6, pp. 278-292. [in French]

Eglin T (2005). Impact de l'hydromorphie et la topographie sur la variabilité spatiale des stocks de carbone en forêt de Fougères (Ille-etVilaine) [Impact of waterlogging and topography on the spatial variability of carbon stocks in the forest of Fougères (Ille-et-Vilaine)]. Thèse Institut National Agronomique, Paris-Grignon, France, pp. 50. [in French]

El-Badri N, Abadie M (2000). Observations on the dynamic of Diplodia mutila Fr apud Mont. development on the cork-oak, Quercus suber L, in Morocco. Cryptogamie Mycologie 21 (4): 235248. - doi: 10.1016/S0181-1584(00)01052-6

Elser JJ, Bracken MES, Cleland EE, Gruner DS, Harpole WS, Hillebrand H, Ngai JT, Seabloom EW, Shurin JB, Smith JE (2007). Global analysis of nitrogen and phosphorus limitation of primary producers in freshwater marine and terrestrial ecosystems. Ecology Letters 10 (12): 1135-1142. - doi: 10.1111/j.1461-0248.2007.01113.x Emberger L (1939). Aperçu général sur la végétation du Maroc. Commentaire de la carte phytogéographique du Maroc au 1/500 000 [Overview on the vegetation of Morocco. Commentary of the phytogeographical map of Morocco 1/500 000]. Veröffentlichungen des Geobotanischen Forschungsinstitutes Rübel in Zürich 14: 40-157. [in French]

Evans J, Fernandez IJ, Rustad LE, Norton SA (2001). Methods for evaluating fractions in forest soil: a review. Maine Agricultural and Forest Experiment Station Technical Bulletin 178: 34-45. [online] URL: http://digitalcommons.libra ry.umaine.edu/aes_techbulletin/30/

FAO (2006). Global Forest Resources Assessment 2005. Progress towards sustainable forest management. FAO Forestry Paper 147, FAO, Rome, Italy, pp. 320. [online] URL: http:// www.fao.org/forestry/fra/fra2005/fr

FAO/IUSS (2006). IUSS Working Group WRB World reference base for soil resources 2006 
( $2^{\text {nd }}$ edn). World Soil Resources Reports no. 103, FAO, Rome, Italy, pp. 128.

Fischlin A, Midgley GF, Price JT, Leemans R, Gopal B, Turley C, Rounsevell MDA, Dube OP, Tarazona J, Velichko AA (2007). Ecosystems, their properties, goods and services. In: "Climate Change 2007: Impacts, Adaptation and Vulnerability" (Parry MLO, Canziani OF, Palutikof JP, Van Der Linden PJ, Hanson CE eds). Contribution of working group II to the fourth assessment report of the intergovernmental panel on climate change. Cambridge University Press, Cambridge, UK, pp. 211-272. [online] URL: http://www.researchonline.mq.edu.au/vital/acc ess/services/Download/mq:7542/DS01

Gonzalez M, Augusto L, Gallet-Budynek A, Xue J, Yauschew-Raguenes N, Guyon D, Trichet P, Delerue F, Niollet S, Andreasson F, Achat DL, Bakker MR (2013). Contribution of understory species to total ecosystem aboveground and belowground biomass in temperate Pinus pinaster Ait forests. Forest Ecology and Management 289: 38-47. - doi: 10.1016/j.forec0.2012.10. 026

Ghaioule D, Lumaret JP, Rochat D, Maatouf N, Niogret J (2007). Evaluation des dégats par les vers blancs (Coleoptera Scarabaeoidea) dans les parcelles de régénération du chêne-liège (Quercus suber L) en forêt de la Mamora (Maroc) et recherche de médiateurs chimiques pour une lutte biologique [Assessment of damage by white grubs (Coleoptera Scarabaeoidea) in regeneration plots of cork oak (Quercus suber $\mathrm{L}$ ) in the forest of Mamora (Morocco) and research of chemical mediators for biological control]. Annales de la Société Entomologique de France 43 (1): 1-8. [in French] - doi: 10.1080/00379271.2007.106 97488

Hansen J, Sato M (2004). Greenhouse gas growth rate. Proceedings of the National Academy of Sciences USA 101: 16109-16114. - doi: 10.1073/pnas.0406982101

IPCC (2007). Climate change 2007: a synthesis. Report Summary for Policymakers, Intergovernmental Panel on Climate Change, IPCC Secretariat, Geneva, Switzerland, pp. 22.

IPCC (2013). Climate change 2013: the physical science basis. Contribution of Working Group I to the Fifth Assessment Report of the Intergovernmental Panel on Climate Change (Stocker $T F$, Qin D, Plattner G-K, Tignor M, Allen SK, Boschung J, Nauels A, Xia Y, Bex V, Midgley PM eds) Cambridge University Press, Cambridge, UK and New York, NY, USA, pp. 1535.

Jackson RB, Mooney HA, Schulze ED (1997). A global budget for fine root biomass, surface area and nutrient contents. Proceedings of the National Academy of Sciences USA 94: 73627366. - doi: 10.1073/pnas.94.14.7362

Jandl $R$, Lindner $M$, Vesterdal L, Bauwens B, Baritz R, Hagedorn F, Johnson DW, Minkkinen K, Byrne KA (2007). How strongly can forest management influence soil carbon sequestration? Geoderma 137: 253-268. - doi: 10.1016/j. geoderma.2006.09.003

Laaribya S (2006). Il faut sauver la forêt de la Mamora (Maroc) [Saving the forest of Mamora (Morocco)]. Forêt Meditérraneenne 27 (1): 6572. [in French] [online] URL: http://documents. irevues.inist.fr/handle/2042/39573

Laaribya S, Alaoui A, Gmira N, Gmira N (2013).
Contribution à l'évaluation de la pression pastorale dans la forêt de la Maamora. Parcours forestiers et surpaturage [Contribution to the assessment of grazing pressure in the forest of Maamora. Forest paths and overgrazing]. Nature et Technologie C- Sciences de l'Environnement 10: 39-50. [in French]

Lal R (2005). Forest soils and carbon sequestration. Forest Ecology and Management 220: 242258. - doi: 10.1016/j.foreco.2005.08.015

Laouina A, Aderghal M, Al Karkouri J, Antari M, Chaker M, Laghazi Y, Machmachi I, Machouri N, Nafaa R, Naïmi K, Nouira A, Sfa M (2010). The efforts for cork oak forest management and their effects on soil conservation. Forest Systems 19 (2): 263-277. - doi: 10.5424/fs/201019201320

Lecointe S, Nys C, Walter C, Forgeard F, Huet S, Recena P, Follain S (2005). Estimation of carbon stocks in a beech forest (Fougères Forest): extrapolation from plots to the whole forest. Annals of Forest Science 25: 432-451.

Le Goff N, Ottorini JM (2001). Root biomass and biomass increment in a beech (Fagus sylvatica L) stand in North-east France. Annals of Forest Science 58: 1-13. - doi: 10.1051/forest:2001104

Lepoutre B (1967). Excursion au Maroc. Description des régions traversées. Chapitre VII: La Mamora [Excursion to Morocco. Description of the regions crossed. Chapter VII: The Mamora]. Les Cahiers de la Recherche Agronomique 1 (2): 279-295. [in French]

Lossaint P, Rapp M (1971). Répartition de la matière organique, productivité et cycle des éléments minéraux dans des écosystèmes de climat méditerranéen. [Distribution of organic matter, productivity and cycling of mineral elements in Mediterranean ecosystems]. In: Proceedings of the Symposium "Productivity of forest ecosystems" (Duvigneaud $\mathrm{P}$ ed), Brussels (Belgium) 27-31 Oct 1969. UNESCO, Paris, France, pp. 597-617. [in French]

Lumaret R, Tryphon-Dionnet $M$, Michaud $H$, Sanuy A, Ipotesi E, Born C, Mir C (2005). Phylogeographical variation of chloroplast DNA in cork oak (Quercus suber). Annals of Botany 96: 853-861. - doi: 10.1093/aob/mci237

MacDicken KG (1997). A guide to monitoring carbon storage in forestry and agroforestry projects. Winrock International Arlington, VA, USA, pp. 87.

Makhloufi M, Abourouh M, El Harchaoui $\mathrm{H}$ (2008). Structure du peuplement, tarifs de cubage et essais de traitements sylvicoles dans la subéraie de Chefchaouen [Stand structure, volume tables and tests of silvicultural treatments in cork oak forests of Chefchaouen]. Annales de la Recherche Forestière au Maroc 39: 175177. [in French] [online] URL: http://cat.inist.fr/? aModele $=$ afficheN\&cpsidt $=21771344$

Makipaa R, Karjalainen T, Pussinen A, Kellomaki $S$ (1999). Effects of climate change and nitrogen deposition on the carbon sequestration of a forest ecosystem in the boreal zone. Canadian Journal of Forest Research 29 (10): 14901501. - doi: 10.1139/x99-123

Mao R, Zeng DH, Hu YL, Li LJ, Yang D (2010). Soil organic carbon and nitrogen stocks in an agesequence of poplar stands planted on marginal agricultural land in Northeast China. Plant and Soil 332 (1-2): 277-287. - doi: 10.1007/s11104-010-
0292-7

Meersmans J, Van Wesemael B, Van Molle M (2009). Determining soil organic carbon for agricultural soils: a comparison between the Walkley and Black and the dry combustion methods (north Belgium). Soil Use and Management 25 (4): 346-353. - doi: 10.1111/j.1475-2743. 2009.00242.x

Millikin CS, Bledsoe CS, Techlin J (1997). Woody root biomass of 40 to 90 year-old blue oaks (Quercus douglasii) in western Sierra Nevada Foothills. In: Proceeding of the Symposium "Oak Woodland: Ecology, Management and Urban Interface Issues". San Luis Obispo (CA, USA) 19-22 Mar 1996. General Technical Report PSW-GTR-160, USDA Forest Service, Albany, CA, USA, pp. 83-89.

Montes N, Bertaudière-Montes $\mathrm{V}$, Badr W, Zaoui $\mathrm{H}$, Gauquelin Th (2002). Biomass and nutrient content of a semi-arid mountain ecosystem: the Juniperus thurifera $L$ woodland of Azzaden Valley (Morocco). Forest Ecology and Management 166: 35-43. - doi: 10.1016/S0378-1127(01)0o 660-0

Nadelhoffer KJ, Raich JW (1992). Fine root production estimates and belowground carbon allocation in forest ecosystems. Ecology 73: 11391390. - doi: 10.2307/1940664

Norby RJ, DeLucia EH, Gielen B, Calfapietra C, Giardina CP, King JS, Ledford J, McCarthy HR, Moore DJP, Ceulemans R, De Angelis P, Finzi $A C$, Karnosky DF, Kubiske ME, Lukac M, Pregitzer KS, Scarascia-Mugnozza GE, Schlesinger $\mathrm{WH}$, Oren $\mathrm{R}$ (2005). Forest response to elevated $\mathrm{CO}_{2}$ is conserved across a broad range of productivity. Proceedings of the National Academy of Sciences USA 102: 18052-18056. - doi: 10.1073/pnas.0509478102

Pajot $G$ (2006). Approche économique de la fonction de séquestration de carbone par les forêts. Application au massif des Landes de Gascogne [Economic approach to carbon sequestration function by forests. Application to the forest range Landes de Gascogne]. Ph. D. thesis, Université Bordeaux IV, Bordeaux, France, pp. 266. [in French]

Pan Y, Birdsey RA, Fang J, Houghton R, Kauppi PE, Kurz WA, Phillips OL, Shvidenko A, Lewis SL, Canadell JG, Ciais P, Jackson RB, Pacala SW, McGuire AD, Piao S, Rautiainen A, Sitch $S$, Hayes D (2011). A large and persistent carbon sink in the world's forests. Science 333: 988993. - doi: 10.1126/science.1201609

Pansu M (2006). Chimie du sol et modélisation du cycle du carbone et de l'azote [Soil chemistry and modeling of carbon and nitrogen cycles]. Thèse, Université de Bourgogne, Digione, France, pp. 210. [in French] [online] URL: http:// www.documentation.ird.fr/hor/fdi:010036220

Pardé J (1966). Forêts et reboisements à haute productivité en France [High-productivity forests and reforestation in France]. Revue Forestière Française 18 (11): 718-724. [in French] - doi: 10.4267/2042/24782

Peng C, Liu J, Apps M, Dang Q, Kurz W (2000). Quantifying Ontario's forest carbon budget. 1. Carbon stock and flux of forest ecosystems in 1990. Forest Research Report 158: 123-137. [online] URL: http://www.cabdirect.org/abstrac ts/20023081270.html

Peichl M, Arain AA (2006). Above- and below- 
ground ecosystem biomass and carbon pools in an age-sequence of temperate pine plantation forests. Agricultural and Forest Meteorology 140: 51-63. - doi: 10.1016/j.agrformet.2006.08.0 04

Porté $A J$, Samalens JC, Dulhoste R, Teissier du Cros R, Bosc A, Meredieu C (2009). Using cover measurements to estimate aboveground understory biomass in Maritime pine stands. Annals of Forest Science 66: 307-317. - doi: 10.1051/ forest/2009005

Pulido-Fernández M, Schnabel S, Francisco J, Contador L, Mellado IM, Pérez Raúl O (2013). Soil organic matter of Iberian open woodland rangelands as influenced by vegetation cover and land management. Catena 109: 13-24. - doi: 10.1016/j.catena.2013.05.002

Rapp M, Santa-Regina I, Rico M, Gallego HA (1999). Biomass, nutrient content, litterfall and nutrient return to the soil in Mediterranean oak forests. Forest Ecology and Management 119: 39-49. - doi: 10.1016/S0378-1127(98)00508-8 Ritson P, Sochacki S (2003). Measurement and prediction of biomass and carbon content of Pinus pinaster trees in farm forestry plantations, south-western Australia. Forest Ecology and Management 175: 103-117. - doi: 10.1016/SO3 78-1127(02)00121-4

Robert M (2002). Rapport sur les ressources en sols du monde [Report on the world's soil resources]. FAO, Rome, Italy, pp. 76. [in French] Rodríguez-Murillo JC (2001). Organic carbon content under different types of land use and soil in peninsular Spain. Biology and Fertility of Soils 33: 53-61. - doi: 10.1007/s003740000289

Rondeux M (1993). La mesure des arbres et des peuplements forestiers [The measurement of trees and forest stands]. Les presses agronomiques de Gembloux, Gembloux, Belgium, pp. 544. [in French] [online] URL: http://orbi.ulg.ac. be/handle/2268/108229

Ruiz-Peinado R, Río M, Montero G (2011). New models for estimating the carbon sink capacity of Spanish softwood species. Forest Systems 20: 176-188. - doi: 10.5424/fs/2011201-11643
Ruiz-Peinado R, Montero G, Del Rio M (2012). Biomass models to estimate carbon stocks for hardwood tree species. Forest Systems 21: 4252. - doi: 10.5424/fs/2112211-02193

Ruiz-Peinado R, Bravo-Oviedo A, Lopez-Senespleda E, Montero G, Rio M (2013). Do thinnings influence biomass and soil carbon stocks in Mediterranean pinewoods? European Journal of Forest Research 132: 253-262. - doi: 10.1007/s1 0342-012-0672-z

Sabir M, Roose E (2002). Effects of soil types and vegetal cover on soil carbon stock and runoff/erosion risks in the western Rif's Mediterranean mountains (Morocco). Bulletin Réseau Erosion, Institut de Recherche pour le Développement, Montpellier 22: 144-154.

Sabo KE, Sieg CH, Hart SC, Bailey JD (2009). The role of disturbance severity and canopy closure on standing crop of understory plant species in ponderosa pine stands in northern Arizona, USA. Forest Ecology and Management 257: 1656-1662. - doi: 10.1016/j.foreco.2009.01.006

SEIFN (2006). Service de l'inventaire forestier national, haut commissariat aux eaux et forêts et à la lutte contre la désertification [National forestry inventory service, high commission for water and forests and the fight against desertification]. Rabat, Maroc, web site. [in French] [online] URL: http://www.eauxetforets.gov. $\mathrm{ma} / \mathrm{fr} /$ text.aspx?id=1062\&uid $=75$

Schlesinger WH (2000). Soil respiration and the global carbon cycle. Biogeochemistry 48: 7-20. doi: 10.1023/A:1006247623877

Tirez K, Vanhoof C, Hofman S, Deproost P, Swerts M, Salomez J (2014). Estimating the contribution of sampling, sample pretreatment, and analysis in the total uncertainty budget of agricultural soil $\mathrm{pH}$ and organic carbon monitoring. Communications in Soil Science and Plant Analysis 45 (7): 984-1002. - doi: 10.1080/00103624.2013.867056

Vadeboncoeur MA, Hamburg SP, Yanai RD (2007). Validation and refinement of allometric equations for roots at northern hardwoods. Canadian Journal of Forest Research 37: 1777-
1783. - doi: 10.1139/X07-032

Walkley J, Black W (1934). An experimentation of the Degtjareff method for determining soil organic matter and a proposed modification of chromic acid titration method. Soil Science 37: 29-38. - doi: 10.1097/00010694-193401000-0000 3

Yanai RD, Stehman SV, Arthur MA, Prescott CE, Friedland AJ, Siccama TG, Binkley D (2003). Detecting change in forest floor carbon. Soil Science Society of America Journal 67: 15831593. - doi: 10.2136/sssaj2003.1583

Yanai RD, Levine CR, Green MB, Campbell JL (2012). Quantifying uncertainty in forest nutrient budgets. Journal of Forestry 110 (8): 448456. - doi: 10.5849/jof.11-087

\section{Supplementary Material}

\section{Appendix 1}

Fig. S1 - Location of the studied cork oak forest of Mamora. Inset on upper left shows its position in Morocco. All stands included in this study are located within cantons $A$ and $B$ (western part of the larger Mamora forest).

Fig. S2 - Relationship between overall height and circumference at breast height $(1.30 \mathrm{~m})$.

Fig. 53 - The residuals of (a) eqn. 1, and (b) eqn. 2, where $C_{130}$ is the circumference at breast height of the sampled trees (in $\mathrm{m}$ ).

Tab. S1 - The equations tested for the volume estimations.

Tab. S2 - The models adjusted for the total volume (trunk and branches).

Link: Oubrahim_1364@supploo1.pdf 